\title{
The role of salt tectonics and overburden in the generation of overpressure in the Dutch North Sea area
}

\section{S. Nelskamp ${ }^{*}$, J.M. Verweij \& N. Witmans}

TN0 - Geological Survey of the Netherlands, Princetonlaan 6, 3584 CB Utrecht, the Netherlands.

* Corresponding author. Email: susanne.nelskamp@tno.nl.

Manuscript received: October 2011, accepted: October 2012

\begin{abstract}
In this paper we study the effects of timing of salt movement and mechanical compaction on the generation of overpressures in Mesozoic rocks. To that end we apply 2D basin modelling on two N-S trending cross sections in the Dutch Central Graben and Terschelling Basin, respectively. Several overpressuring scenarios were calculated by modifying the mechanical compaction of the sealing layer, the rate of sedimentation, and the timing of salt movement. Pressure and porosity measurements from several wells along the cross sections were used as calibration data. The results show that rapid sedimentation and early compaction of Pliocene to Quaternary mudstones explain most of the overpressures in the Cretaceous and Jurassic rocks. The modifications of the mechanical compaction of the Upper Cretaceous Chalk Group performed in this study could not explain the overpressure anomalies in the southern part of the Dutch Central Graben. Processes such as chemical compaction are probably more important in this respect. Overpressures in the Triassic are mainly controlled by the timing of salt movement and the closure of lateral seals. This study has lead to a better understanding of the processes that generate overpressures and those that are involved in their lateral distribution. The integration of modelling scenarios and information on the timing of seal formation enables to define new play concepts and is important for the assessment of possible drilling hazards as well.
\end{abstract}

Keywords: overpressure, Terschelling Basin, Dutch Central Graben, reservoirs, Jurassic, Cretaceous, Triassic, salt movement, disequilibrium compaction

\section{Introduction}

In this study we use basin modelling to assess the spatial and temporal evolution of pressures and to examine factors and processes influencing the pressure systems in the Terschelling Basin and the southern part of the Dutch Central Graben. A better understanding of the observed pressure distribution through time and space helps defining new prospects for hydrocarbon exploration by providing models for seal strength and timing. This understanding aids the proper assessment of drilling hazards. Basin modelling has been used frequently in the TNO mapping program of the Netherlands offshore (2005-2010) to answer this kind of questions related to the dynamics of the Dutch subsurface. Relevant results of the mapping program for this study include a detailed stratigraphic model of the Terschelling Basin and the southern part of the Dutch Central Graben (Verweij \& Witmans, 2009), an inventory of rock and fluid properties (Benedictus, 2007), and a 3D basin model of the area (Verweij et al., 2012). Two 2D extractions were taken from this $3 \mathrm{D}$ basin model and refined for the study of the pressure systems under scrutiny. Several scenarios were developed for the $2 \mathrm{D}$ lines that constrain the timing of the formation of the top and side seals and the lithological parameters necessary to model the observed overpressures. Porosity measurements were added to the model as additional calibration data.

The pore fluids in the sediments of the Terschelling Basin (TB) and the southern part of the Dutch Central Graben (DCG) are overpressured from the Lower Cenozoic mudstones downward. Excess pore fluid pressures of more than $4 \mathrm{MPa}$ above hydrostatic occur in Lower Cenozoic sediments (Verweij et al., 2012). The highest overpressure values were measured in reservoirs of the Lower Germanic Triassic Group (reaching $37 \mathrm{MPa}$ ) and the Upper Rotliegend Group (exceeding $40 \mathrm{MPa}$ ). All pressure measurements were taken in wells and large lateral variations in pore fluid pressures are observed, especially in the Triassic units. 


\section{Background}

\section{Previous studies}

The competition between pressure-generating mechanisms and pressure-dissipating water flow controls the overpressure distribution. The processes that influence the generation of overpressures can be categorised as stress related or volume related. Stress-related processes include lateral stress due to tectonic compression or vertical stress due to sedimentary loading (Mann \& MacKenzie, 1990; 0sborne \& Swarbrick, 1997). Volume-related stress is associated with an increase of fluid volume in pore space, for instance due to hydrocarbon generation (Hedberg, 1974; Luo \& Vasseur, 1996).

The pressure system of the Jurassic interval in the North Sea has been studied by several authors in detail outside the Dutch sector. Holm (1998) analysed the overpressures in the UK part of the Central Graben and concluded that for the Jurassic sandstones these are most likely related to hydrocarbon generation from the Kimmeridge Clay source rock. The observed overpressures in the Jurassic reservoirs in Holm's study reach almost lithostatic pressure conditions. DiPrimio \& Neumann (2008) state that the observed overpressures in the Jurassic and Triassic reservoirs in the UK sector of the North Sea cannot be calibrated by using basin modelling if only one pressure generating method (generation of $\mathrm{HC}$ or disequilibrium compaction) is used. Moss et al. (2003) believe that stress-related mechanisms, such as sedimentary loading, and gas generation are the two dominant causes contributing to overpressures in Central North Sea basins. In the three last-mentioned publications, the reported overpressures in Cretaceous and Cenozoic rocks are lower than in the Jurassic rocks. For the Cretaceous and Cenozoic rocks in the UK and Danish sectors, respectively, Holm (1998) and Vejbaek (2008) identified disequilibrium compaction, mainly due to high sedimentation rates in the Cenozoic, as the main overpressure generating mechanism. Both Verweij (2006) and Vejbaek (2008) observed a good correlation between the thickness of Cenozoic and Quaternary sediments and measured overpressures in the Late Cretaceous Chalk Formation.

\section{Geological and fluid flow setting}

\section{Geological setting}

The study area is situated in the former Variscan foreland basin that evolved into the Southern Permian Basin in late Paleozoic times. During the Mesozoic the area experienced differential tectonic movements that caused the development of the main present-day structural elements: the Dutch Central Graben (DCG), Terschelling Basin (TB) and adjacent Central Offshore (COP), Schill Grund (SGP) and Groningen platforms (GP; Ziegler, 1990; Kombrink et al., this issue; Fig. 1). The associated tectonostratigraphic sequences are separated by three major phases of tectonic activity and erosion, namely the Saalian, Mid- to Late Kimmerian and Sub-Hercynian to Laramide tectonic phases (e.g. Glennie, 1986; De Jager, 2003; Ziegler, 1990, 2005). The main phase of extension in the Central Graben occurred during the Late Kimmerian phase (Middle Oxfordian to Early Kimmeridgian), after which the area continued to subside due to thermal subsidence (Rattey \& Hayward, 1993).

The geologic evolution of the DCG and TB is illustrated by burial histories at two representative well locations (Figs 2 and 3). These burial histories show three main phases of rapid burial and sedimentation (sedimentation rates $>100 \mathrm{~m} / \mathrm{Ma}$ ) that coincide with the main tectonic events in the area, i.e. during the Late Carboniferous, Late Permian to Early Triassic and during Pliocene to Quaternary times (Ziegler, 1990; Figs 2 and 3). A fourth Late Jurassic to Early Cretaceous phase can only be seen in the TB. Both areas are at their maximum burial depth at present.

Three main erosion phases in the study area were inferred from hiatuses in the sedimentary record; the Saalian phase at the Carboniferous/Permian transition, the Mid-Kimmerian phase in the Middle Jurassic (only in the TB) and the Sub-Hercynian to Laramide phase in the Late Cretaceous (mostly in the DCG and western TB; De Jager, 2003, 2007). Erosion phases may have had a big influence on the pressure evolution (e.g. erosion can remove or disturb sealing layers, reactivate faults and change the basin geometry due to uplift of an area so that pressure can dissipate faster due to less overburden).

The post-Permian structural and sedimentary development of the area was greatly influenced by the presence of Zechstein evaporites (see Remmelts, 1996; Ten Veen et al., this issue). Movement of Zechstein (Upper Permian) salt in combination with its very low permeability plays an important role both in defining the present-day geometry of basins and in influencing pressure and fluid flow during geological history. For example, salt doming caused uplift and erosion of overlying sealing layers. Salt diapirs and -walls also act as barriers to lateral fluid flow. The depositional thickness of the evaporites was estimated to have been around $650 \mathrm{~m}$ (Verweij \& Witmans, 2009), which is in good agreement with reconstructed depositional thicknesses for this area (Ten Veen et al., this issue). The present-day thickness varies from more than $5000 \mathrm{~m}$ in the salt structures along the borders of the DCG to only a few meters in withdrawal areas (Remmelts, 1996; Ten Veen et al., this issue). Thirty salt structures are located in the study area, which follow the structural trend of the area (Fig. 4; Remmelts, 1996). Based on the geometry of the salt and the unconformable relation with overlying layers, main periods of salt movement seem connected to phases of active fault movement (Remmelts, 1996; Ten Veen et al., this issue). In the northern part of the DCG there is evidence for salt movement as early as the Late Triassic whereas in the southern part of the DCG, salt movement only started in the Late Jurassic (Remmelts, 1996). In the TB, salt movement has started before Middle Jurassic times. In the DCG as well as in the $\mathrm{TB}$, salt movement continued during the Late Jurassic and 


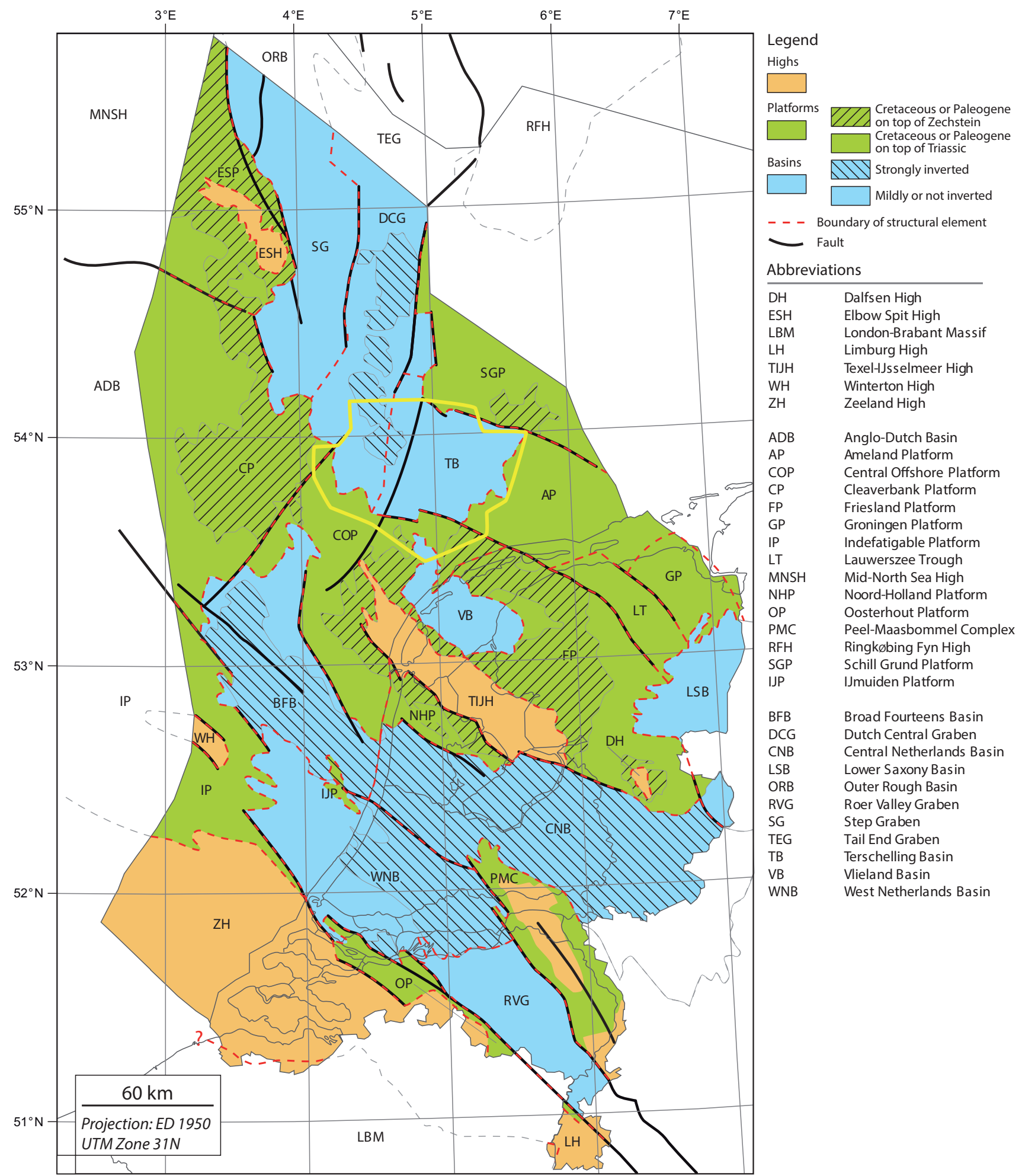

Fig. 1. Structural elements map of the Netherlands and locality of the study area. See Kombrink et al. (this issue) for a complete overview of the structural elements of the Netherlands.

Early Cretaceous. According to Remmelts (1996), the salt structures in the TB show signs of truncation that occurred during this period, which suggests that the salt structures had pierced the overlying sediments by then. During the Late Cretaceous to Paleogene, compression tectonics remobilised the salt as can be seen on the cross sections (Figs 5 and 6 ). Some salt structures continue to move until present day (Verweij \& Witmans 2009; Ten Veen et al., this issue).

Based on the fact that several oil and gas fields are present in the study area, it should be considered that hydrocarbon generation and migration from the source rocks can play a role in the pressure generation and distribution. Gas fields in the 


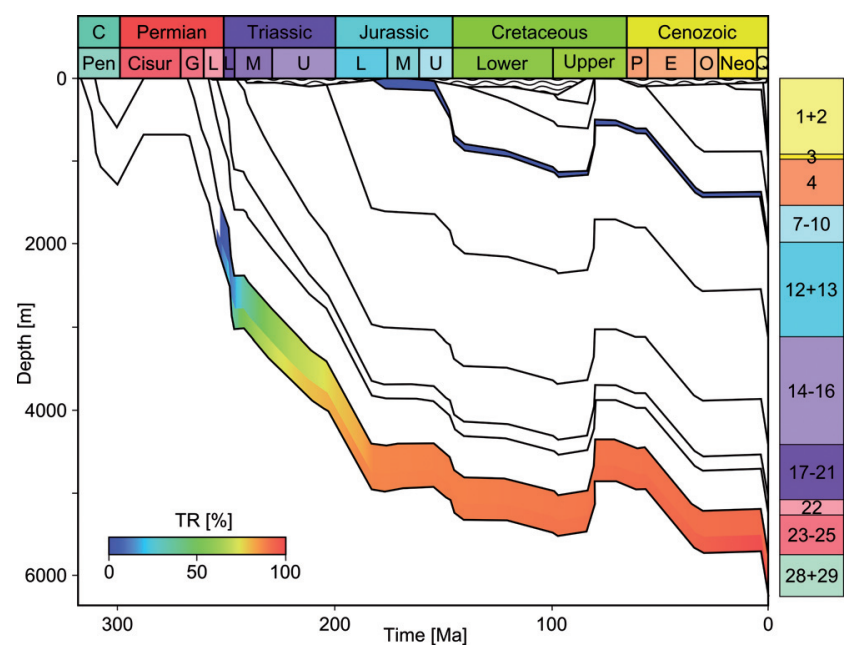

Fig. 2. Burial history diagram of well F17-06 from the northern part of the $D C G$ section with the calculated transformation ratio of the Jurassic and Carboniferous source rocks ( $A-A^{\prime}$ see Fig. 5). For an explanation of the stratigraphy see Table 2.

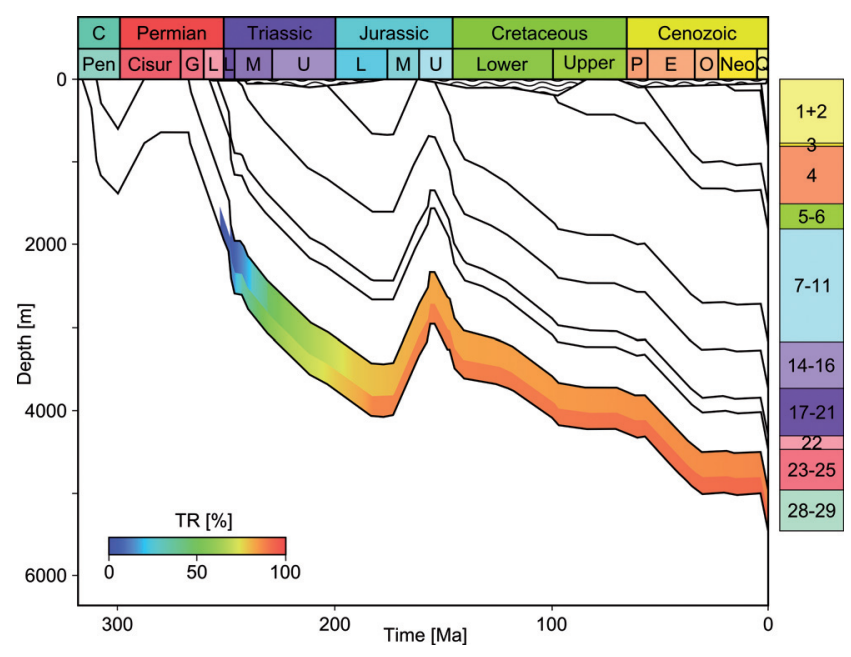

Fig. 3. Burial history diagram of well M01-02 from the northern part of the $T B$ section with the calculated transformation ratio of the Carboniferous source rocks (B-B' see Fig. 6). For an explanation of the stratigraphy see Table 2.

DCG are mainly situated in Lower Triassic and Permian sandstones and oil was found in Upper Jurassic sandstones (e.g. F17-FA). In the TB, gas also occurs in Lower Triassic and Permian sediments and in Upper Jurassic sandstone layers above salt domes. The main gas source rocks are the Carboniferous coals. Oil is believed to originate from the Lower Jurassic Posidonia Shale Formation (De Jager et al., 1996; De Jager \& Geluk, 2007)

\section{Fluid flow setting}

The fluid flow setting reflects the distribution of high and low permeable stratigraphic layers and structures in the subsurface. The high permeable layers (aquifers) in the study area are the sandy Hospital Ground and Step Graben Formations of Late
Carboniferous age, the Lower Slochteren Member of Middle Permian age, the carbonate members of the Zechstein Group of Late Permian age, the Lower Detfurth and Lower Volpriehausen Sandstone Members of Early Triassic age, the Solling Fat Sandstone Member of Middle Triassic age, several sandy units of Late Jurassic age and sands of Quaternary age. The most important units, the Lower Slochteren Member, Early Triassic Sandstone Members and Terschelling Sandstone Member of Late Jurassic age are included in the model.

The most important low permeable units controlling the preservation of overpressures in the TB and southern part of the DCG are the Zechstein salt deposits and structures, and the salt deposits of the Middle Triassic (Röt Formation, Figs 5 and 6). Low permeable clay-rich layers that play an important role in the retardation of pressure in the underlying reservoirs occur throughout the entire stratigraphic sequence.

Based on the distribution of the high and low permeable units, the area can be subdivided into three intervals. The lowermost interval consists of the sandstone units of Lower Permian and Upper Carboniferous age that are capped by the Zechstein evaporites of Late Permian Zechstein Group.

The second interval is composed of Lower Triassic sandstones underlain by Upper Permian evaporites and overlain by Middle and Upper Triassic salt layers. It is laterally restricted by salt structures or sealing faults. Depending on the exact configuration of the surrounding seals, this creates separate pressure compartments in the Triassic. The $2 \mathrm{D}$ section in the southern DCG (A-A'; Figs 4 and 5) transects three different pressure compartments in this second interval. From the northern compartment no pressure measurements in Triassic sandstones are available. The second compartment in the middle of the cross section is highly overpressured, as is the southern compartment (Fig. 5). The 2D section in the TB (B-B'; Figs 4 and 6 ) also transects three compartments. Pressure measurements are lacking from the northern and southern compartments for the Triassic, but measurements from the middle compartment reveal high overpressures in the Triassic sandstones (Fig. 6).

The third interval is situated above the Middle and Upper Triassic salt layer(s). In the Jurassic sandstones, moderately increased overpressures were measured in the whole area. Overpressures decrease towards the inverted centre of the DCG (Fig. 7, Table 1).

\section{Methods}

For this study, two 2D lines (Figs 4, 5 and 6) were extracted from a 3D basin model (Verweij et al., 2012) with the aim to cover all important structures of the basins and to include the maximum number of measured pressure data for calibration. Lithological descriptions, boundary conditions, erosion estimates and calibrated temperatures were transferred from the original 3D model and partly modified for the purpose of this study. Two 2D studies were chosen over a 3D one in order to be able to 


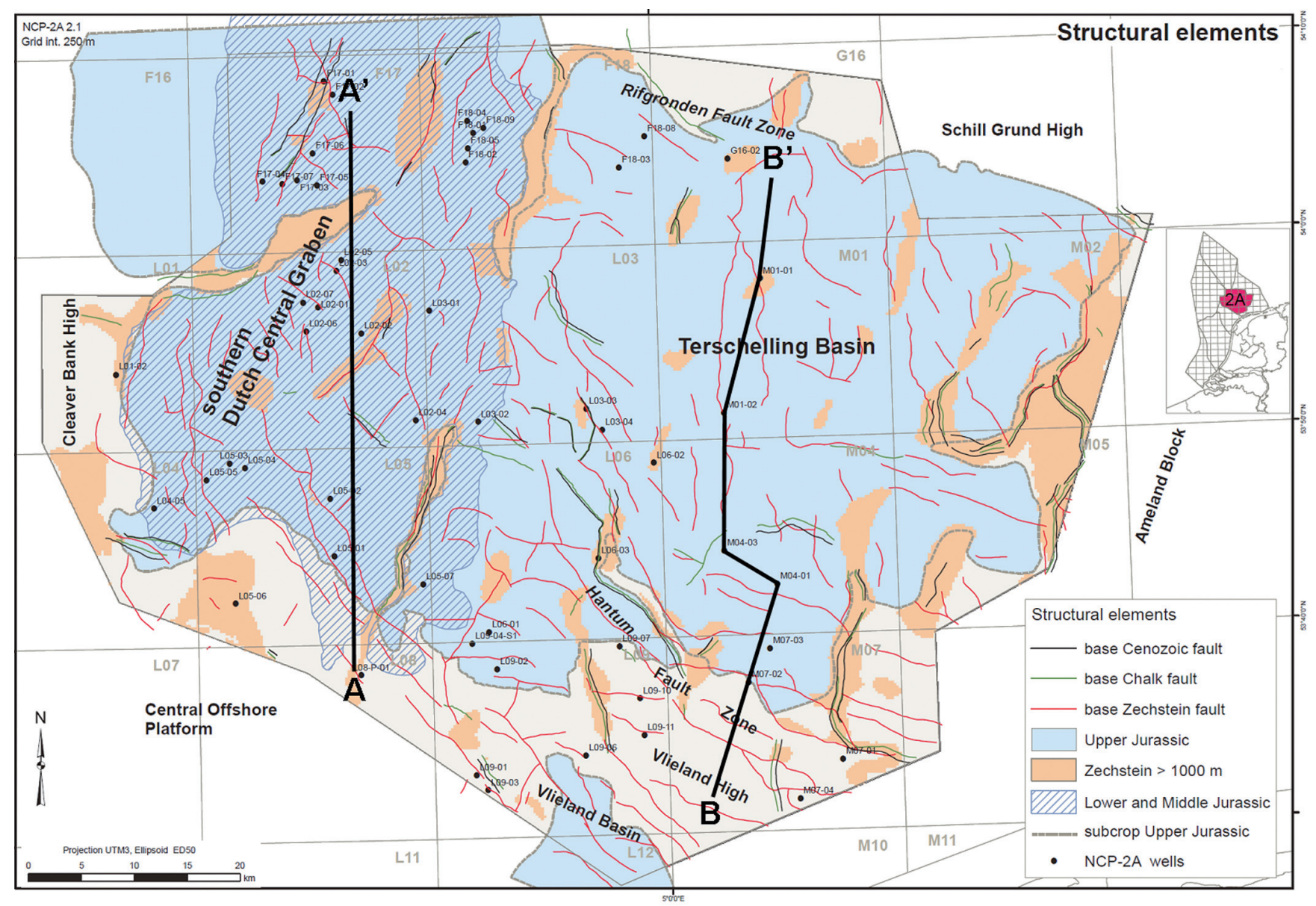

Fig. 4. Structural elements and position of the studied 2D lines (modified after Verweij et al., 2009).

adjust the models more rapidly for the different scenarios. The restrictions related to a $2 \mathrm{D}$ based study, compared to a full 3D study, were deemed non-relevant for the focus of the study. The basin modelling software PetroMod version 10 and 11 (Schlumberger) was used for this study.

In addition, 12 wells with calibration data were selected that are in close vicinity of the sections. Wells F17-06, L02-07, L05-05 and L05-07 are located along the DCG section (Fig. 5) and have present-day temperatures, vitrinite reflectance, porosity and pressure measurements as calibration parameters. Wells M01-01, M01-02, M01-03, M04-01, M04-03 and M07-02 are situated directly on the Terschelling section (Fig. 6). Wells L03-03, L03-04, L06-02 and L06-03 were used for additional calibration and are situated just to the west of the TB cross section. These wells also have present-day temperatures, vitrinite reflectance, porosity and pressure measurements that were used for calibration. Faults were not included in the models.

\section{Assumptions and default set-ups}

General assumptions and conditions underlying the basin modelling include:

- vertical movement only (no lateral deformation of the sediments in the model, except for salt movement);
- salt movement has no direct relation to changes in stress;

- compaction of the basin fill is vertical;

- compaction is mechanical according to vertical effective stress-based rock property model, chemical compaction is not included;

- density of pore water is held constant (no density changes with temperature and salinity);

- pore water and solid rock are incompressible;

- salt is impermeable $\left(\mathrm{K}=10^{-16} \mathrm{mD}\right)$;

- 2D is an acceptable approximation.

PetroMod default set-ups that were initially used in the simulations concern the default lithology-associated mechanical compaction equations and default porosity-permeability relations. Chemical compaction was not taken into account.

In order to calibrate pressure in the $2 \mathrm{D}$ models, several scenarios with different sedimentation, erosion and salt movement times as well as different physical rock properties were calculated. Sedimentary loading is taken into account as a pressure generating mechanism and the timing of salt movement is included because of its influence on fluid flow and pressure retention. For the present study it was decided not to include hydrocarbon generation in the pressure calibration. In the study area only minor or non productive oil 


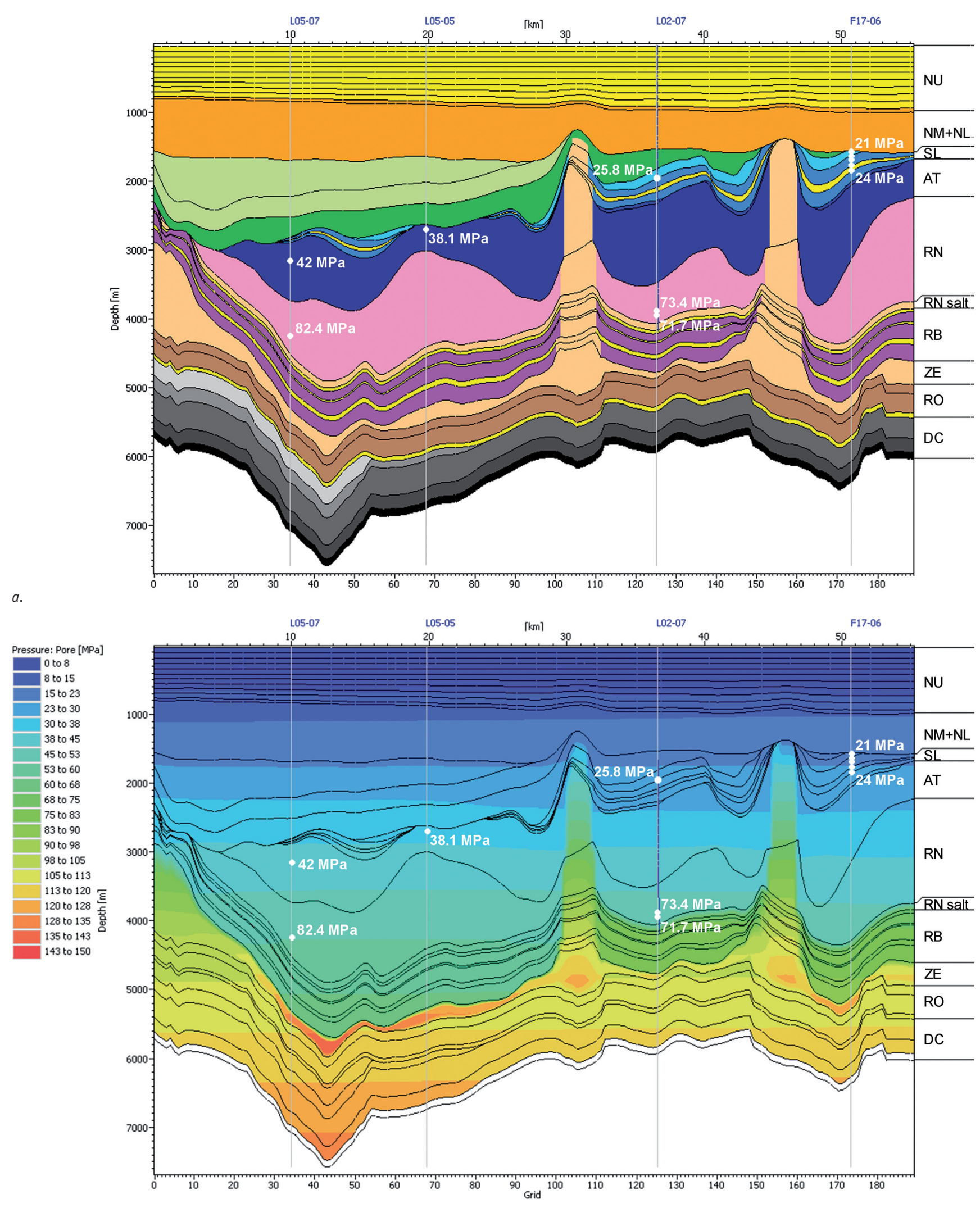

$b$.

Fig. 5. $2 D$ section in the Dutch Central Graben with projected position of the wells and pore pressure calibration measurements on: a. layers and position of the salt diapirs; and b. calculated pore pressure from basin modelling. NU - Upper North Sea Group (Miocene to Quaternary), NL - Lower North Sea Group (Paleogene), CK - Chalk Group (Late Cretaceous), KN - Rijnland Group (Early Cretaceous), SL - Schieland Group (Late Jurassic), AT - Altena Group (Early Jurassic), RN - Upper Germanic Trias Group (Middle and Late Triassic), RB - Lower Germanic Trias Group (Early Triassic), ZE - Zechstein Group (Late Permian), RO - Rotliegend Group (Early and Middle Permian), DC - Limburg Group (Late Carboniferous). Vertical exaggeration is 5. 


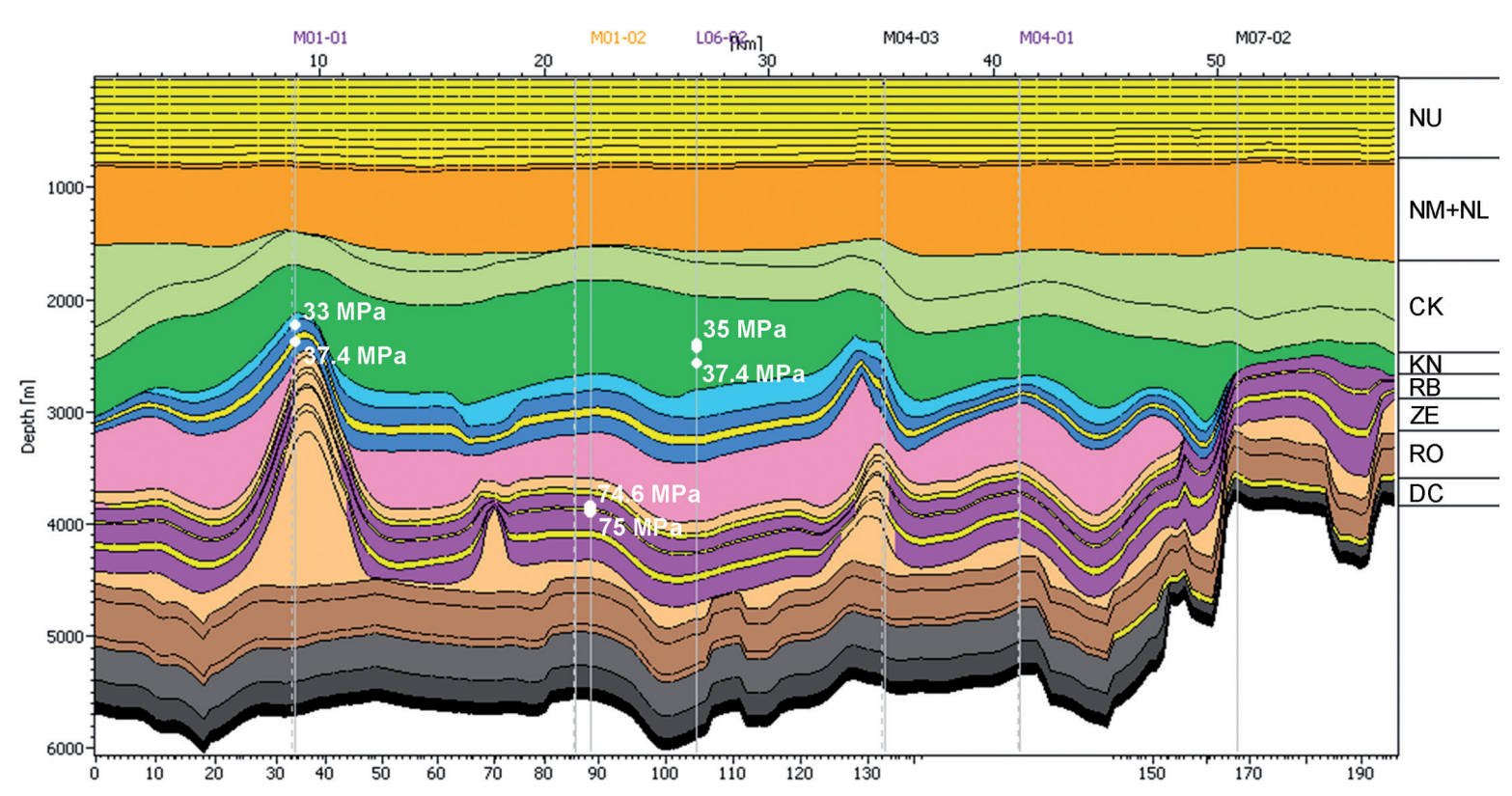

$a$.

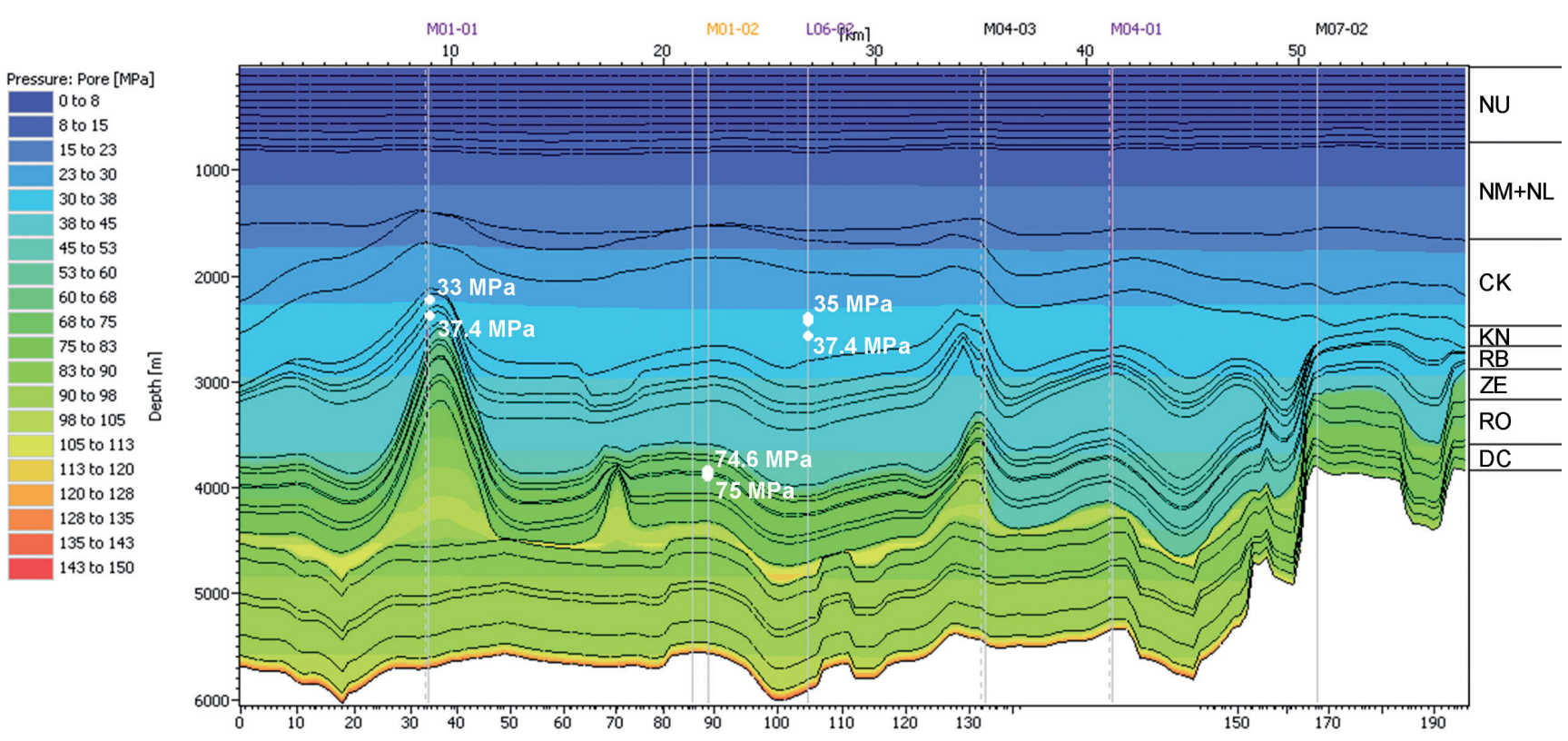

b.

Fig. 6. $2 D$ section in the TB with the projected position of the wells and pore pressure calibration measurements on: a. layers and position of the salt diapirs; and $b$. calculated pore pressure from basin modelling. For an explanation of the abbreviations see Fig. 5. Vertical exaggeration is 5.

fields occur in rocks younger than the Triassic (e.g. F17-FA). 0il has less influence on pressure build up compared to gas and the effect was neglected for the sake of simplicity. Furthermore, the observed overpressure difference between the Jurassic and Cretaceous sediments is not as high as in the area studied by DiPrimio \& Neumann (2008) and Holm (1998), where good HPHT black oil to gas condensate reservoirs were discovered and hydrocarbon generation can have a major influence on overpressure conditions. Several gas fields in the area are situated in rocks of Triassic age and older. These, however, could not be reproduced in the models, which is probably an effect of the 2D character of the models. An effect of the gas on the pressure system of the Triassic and Permian cannot be excluded. The main process, however, was assumed to be the timing of the formation of the lateral and top seal.

\section{Geological input model}

The same geological input model as in the 3D model was used for consistency (Table 2). In addition, to be able to model the pressure generation more accurately, the Cenozoic layers were subdivided for the different scenarios. The subdivision is based on the more detailed lithological subdivision identified in the wells and applied as a ratio to the 2D model. Furthermore new 



Fig. 7. Overpressure measurements from the Upper Jurassic sandstone reservoirs (www.nlog.nl).

Table 1. Fluid pressure variation measured from Repeat Formation Tests (RFT) in the study area (from Verweij \& Witmans, 2009).

\begin{tabular}{|c|c|c|c|c|c|c|}
\hline & Stratigraphic group & Geologic age & $\begin{array}{l}\text { Fluid pressure } \\
(\mathrm{MPa})\end{array}$ & $\begin{array}{l}\text { Excess fluid } \\
\text { pressure }^{*}(\mathrm{MPa})\end{array}$ & $\begin{array}{l}\text { Depth } \\
\text { (mTVDss) }\end{array}$ & $\begin{array}{l}\text { Number } \\
\text { of wells }\end{array}$ \\
\hline \multirow[t]{6}{*}{ Southern Dutch Central Graben } & Lower North Sea & Paleocene to Eocene & $20.7-21.2$ & $4.7-5.4$ & $1526-1528$ & 1 \\
\hline & Chalk & Late Cretaceous & 21.6 & 5.3 & 1583 & 1 \\
\hline & Rijnland & Early Cretaceous & 34.6 & 11.2 & 2253 & 1 \\
\hline & Schieland & Late Jurassic & $21.7-42.3$ & $5-11.5$ & $1595-3161$ & 20 \\
\hline & Lower Germanic Trias & Early Triassic & $52.3-82.7$ & $9.1-37.1$ & $3917-4248$ & 8 \\
\hline & Upper Rotliegend & Middle Permian & 99 & 44.2 & 5032 & 1 \\
\hline \multirow[t]{2}{*}{ Terschelling Basin } & Schieland & Late Jurassic & $32.9-42$ & $9.2-13.7$ & 2251-2859 & 6 \\
\hline & Lower Germanic Trias & Early Triassic & $37-75.2$ & $8.6-33.6$ & $2704-3904$ & 4 \\
\hline
\end{tabular}

* Excess fluid pressure calculated in relation to density corrected hydrostatic pressure.

age determinations were available (Kuhlmann et al., 2006), revealing a much higher accumulation rate for the uppermost Cenozoic succession, compared to values used in the $3 \mathrm{D}$ model.

\section{Boundary conditions}

For the boundary conditions the same water depth curve as in the original 3D model was used (Verweij et al., 2012). The default sediment water interface temperature (SWIT) curve was modified for the Cenozoic and Quaternary (Fig. 8). The new SWIT values are a combination of recent Cenozoic climate reconstructions (e.g. Mosbrugger et al., 2005; Sluijs et al., 2006; Donders et al., 2009) and were adjusted for sediment surface temperatures (Verweij et al., 2012). The models were calculated with a default heat flow of $60 \mathrm{~mW} / \mathrm{m}^{2}$ and a calculated heat flow based on tectonic subsidence (see Verweij et al., 2012). The model boundaries are closed for pressure dissipation.

\section{Calibration data}

The initial temperature and vitrinite reflectance calibration and reconstruction of the erosion events were performed on the initial 3D model and are described in detail by Verweij et al. (2012). The results of the calibration were used in the 2D models.

In addition to the temperature and maturity calibration, mean porosity and formation pressures were gathered and incorporated into the 2D models. Mean porosity and its standard deviation were determined from available wireline log data from wells in or adjacent to the TB and the southern DCG region for the Upper Jurassic Schieland and Scruff Groups, Solling Fat 
Table 2. Conceptual model of the 2D models with new Tertiary age definition.

\begin{tabular}{|c|c|c|c|c|c|}
\hline \multicolumn{2}{|c|}{ Layer } & \multicolumn{2}{|c|}{$\begin{array}{l}\text { Deposition } \\
\text { age (Ma) }\end{array}$} & \multicolumn{2}{|c|}{$\begin{array}{l}\text { Erosion } \\
\text { age }(\mathrm{Ma})\end{array}$} \\
\hline & & From & To & From & To \\
\hline 1 & Upper North Sea Group_top & 1.81 & 0 & 0 & 0 \\
\hline 2 & Upper North Sea Group_bottom & 5.33 & 1.81 & 0 & 0 \\
\hline 3 & Middle North Sea Group & 20.43 & 14.8 & 0 & 0 \\
\hline 4 & Lower North Sea Group & 56.8 & 30.4 & 0 & 0 \\
\hline 5 & Chalk Group_top & 80 & 61.7 & 0 & 0 \\
\hline 6 & Chalk Group_bottom & 99 & 83.5 & 83.5 & 80.5 \\
\hline 7 & Rijnland Group & 140 & 99 & 80.5 & 80 \\
\hline 8 & Schieland Group_Scruff subgroup & 145 & 140 & 0 & 0 \\
\hline 9 & Schieland Group_top & 146.8 & 145 & 0 & 0 \\
\hline & Terschelling Sandstone Formation & 148 & 146.8 & 0 & 0 \\
\hline & Schieland Group_bottom & 154 & 148 & 0 & 0 \\
\hline & Posidonia Shale Formation & 183 & 176 & 173 & 172 \\
\hline & Altena Group & 203.6 & 183 & 172 & 162 \\
\hline 14 & Upper Germanic Trias Group_top & 241 & 203.6 & 162 & 157 \\
\hline & Upper Germanic Trias Group_salt & 243 & 241 & 157 & 156 \\
\hline & Upper Germanic Trias Group_bottom & 245 & 243 & 156 & 154 \\
\hline & Lower Germanic Trias Group_top & 247.6 & 246.2 & 0 & 0 \\
\hline & Lower Detfurth Sandstone Mb. & 247.8 & 247.6 & 0 & 0 \\
\hline 19 & Lower Germanic Trias Group-middle & 248.6 & 247.8 & 0 & 0 \\
\hline 20 & Lower Volpriehausen Sandstone Mb. & 249 & 248.6 & 0 & 0 \\
\hline 21 & Lower Germanic Trias Group_bottom & 254 & 249 & 0 & 0 \\
\hline 22 & Zechstein Group & 258 & 254 & 0 & 0 \\
\hline 23 & Upper Rotliegend Group_top & 260.85 & 258 & 0 & 0 \\
\hline 24 & Upper Rotliegend Group_middle & 266.17 & 260.85 & 0 & 0 \\
\hline 25 & Upper Rotliegend Group_bottom & 267.5 & 266.17 & 0 & 0 \\
\hline 26 & Step Graben/Hospital Ground fms & 308 & 300 & 300 & 292 \\
\hline 27 & Maurits Formation & 310 & 308 & 292 & 288 \\
\hline 28 & Ruurlo Formation & 312 & 310 & 288 & 280 \\
\hline & Baarlo Formation & 316.5 & 312 & 280 & 278 \\
\hline 30 & Basement & 320 & 316.5 & 0 & 0 \\
\hline
\end{tabular}

Sandstone Member of the Upper Germanic Triassic Group, Lower Triassic Main Buntsandstein Subgroup and the Upper Rotliegend Group. The values were derived using the arithmetic mean porosity of calculated porosity over net intervals of the investigated reservoirs (Benedictus, 2007). The available pressure measurements were derived from repeat formation tests (RFT).

\section{Lithology}

Customised mixtures of the standard PetroModv10 and v11 lithologies were used, based on the lithological descriptions for the Dutch subsurface by Van Adrichem Boogaert \& Kouwe (1993). For this study, the compaction relationships (porositydepth and porosity-permeability) of these mixtures were modified for the Cenozoic shales and the Late Cretaceous Chalk to calibrate the pressure measurements.

\section{Cenozoic shales}

The compaction models, that are used to calculate the porosity-depth relationship of a lithology, were changed with the introduction of the new lithologies in PetroMod v11. The new default PetroMod lithologies work with Athy's law that calculates the porosity $\varphi$ at depth $\mathrm{z}$ as

$$
\Phi(\mathrm{z})=\Phi_{1}+\left(\Phi_{0}-\Phi_{1}\right) \mathrm{e}^{-\mathrm{kz}}
$$

with $\varphi_{0}$ being the initial porosity of the rock, $\varphi_{1}$ being the minimum porosity and $\mathrm{k}$ being the rock specific Athy parameter (Athy, 1930).

The old set of default lithologies uses the Compressibility model as the model for calculating the mechanical compaction. This model calculates the decrease of porosity with depth as an exponential decrease of the porosity vs. effective stress curve from an initial, minimum compressibility $C_{0}$ to a maximum compressibility $\mathrm{C}_{1}$.

$$
\log C(\Phi)=\frac{\left(\Phi_{0}-\Phi\right)}{\left(\Phi_{0}-\Phi_{1}\right)} \log C_{1}+\frac{\left(\Phi-\Phi_{1}\right)}{\left(\Phi_{0}-\Phi_{1}\right)} \log C_{0}
$$

The difference between these two models can be seen in Fig. 9 and Table 3. We also compared four porosity-permeability relationships: the default shale in PetroMod v11 (new default model), the old default shale of PetroMod v10 (old default model), a user-defined relationship based on data from Broichhausen et al. (2005; new porosity model) and another user-defined relationship based on a combination of data from Broichhausen et al. (2005) and Yang \& Aplin (2007). Table 4 and Figure 10 present the different porosity-permeability relationships.

The permeability evolution of the two user-defined curves is very similar except for the lowermost part and they fit the curve of the old default shale lithology quite well (Fig. 9). The effect of these different relationships on the simulated pressures is shown in Fig. 11.

Several scenarios were calculated using different combinations of porosity and permeability models to determine which combination gave the best results. In general, modifications of the mechanical compaction model (porosity-depth relationship) show a bigger effect on the generation of overpressure than modifications of the porosity-permeability relationship. The results of the scenarios based on Broichhausen et al. (2005) and Yang \& Aplin (2007) and the compressibility model for the porosity-permeability relationship (later called modified shale lithology) are presented here, as they showed the best calibration results.

\section{Late Cretaceous chalk}

In the southern part of the DCG section as well as in the whole TB section the Upper Cretaceous Chalk Group is still present. Verweij (2006) compared pressures from different areas offshore 


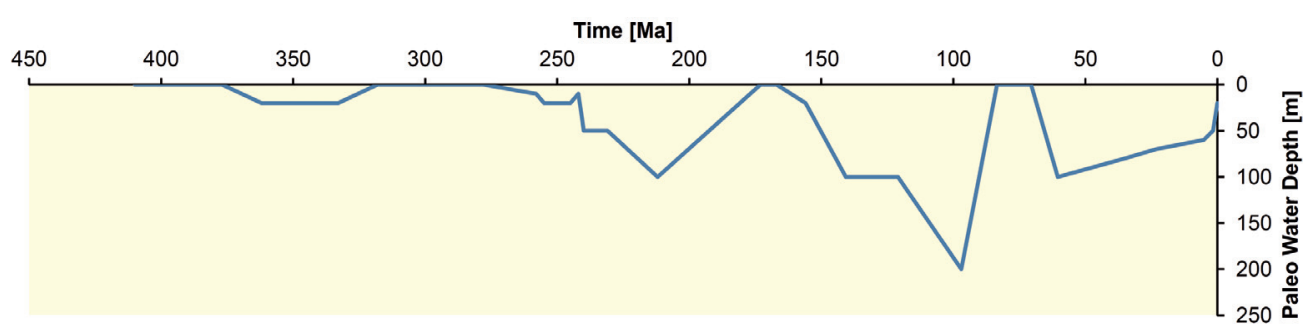

Fig. 8. Boundary conditions: a. Palaeo Water Depth (PWD);

b. Sediment Water Interface Temperature SWIT; and c. Heat Flow (HF) of the models.

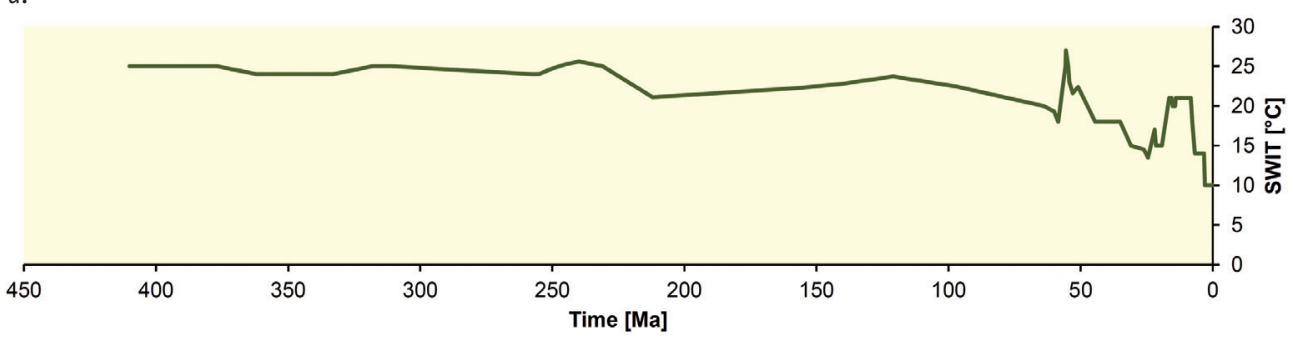

$b$.



the Netherlands and linked the generation of overpressures in Jurassic reservoirs to hydraulic behaviour of the Chalk. The Chalk can either act as aquifer or aquitard depending on the

overpressures can be observed between the measurements from the Upper Cretaceous Chalk Group and the underlying Upper Jurassic to Early Cretaceous sediments, suggesting that the burial history and/or depositional environment. An increase in Chalk acts as permeability barrier. The applied chalk lithology

Fig. 9. Comparison of the two mechanical compaction models.

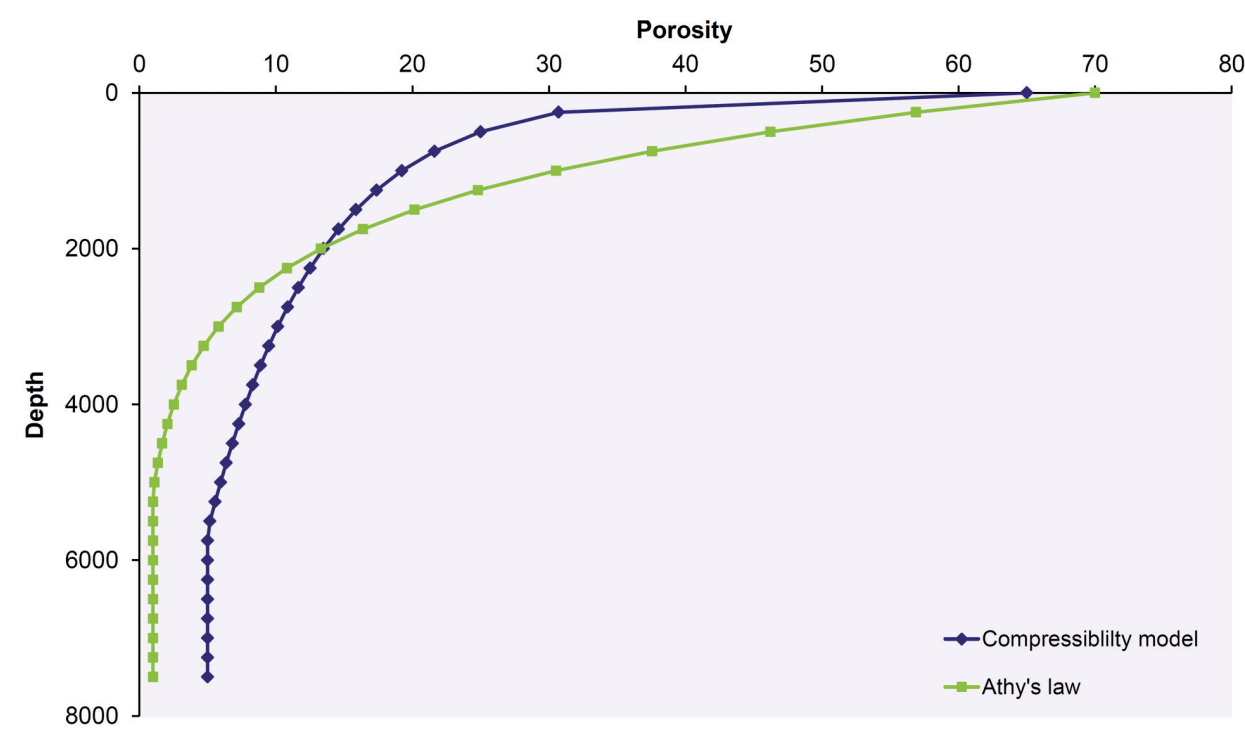

Table 3. Comparison of the input parameters of the different compaction models.

\begin{tabular}{llllllll}
\hline & $\begin{array}{l}\text { Density } \\
\left(\mathbf{k g} / \mathbf{m}^{3}\right)\end{array}$ & $\begin{array}{l}\text { Initial } \\
\text { porosity }(\%)\end{array}$ & $\begin{array}{l}\text { Minimum } \\
\text { porosity }(\%)\end{array}$ & $\begin{array}{l}\text { Compaction } \\
\text { model key }\end{array}$ & $\begin{array}{l}\text { Compressibility } \\
\text { maximum }\left(\mathbf{1 0}^{-7} \mathbf{k P a}\right)\end{array}$ & $\begin{array}{l}\text { Compressibility } \\
\text { minimum }\left(\mathbf{1 0}^{-7} \mathbf{k P a}\right)\end{array}$ & $\begin{array}{l}\text { Athy's } \\
\text { factor k }\end{array}$ \\
\hline Athy's law & 2700 & 0.7 & 0.01 & Athy's law (Depth) & - & - & 0.83 \\
Compressibility model & 2680 & 0.65 & 0.05 & Compressibility model & 60000 & 10 & - \\
\hline
\end{tabular}


Table 4. Porosity-permeability values of different models.

\begin{tabular}{|c|c|c|c|c|c|c|c|c|c|c|}
\hline & \multicolumn{10}{|c|}{ Permeability $(\log \mathrm{mD})$ at $\mathrm{x} \%$ porosity } \\
\hline & 1 & 5 & 10 & 20 & 25 & 30 & 40 & 50 & 70 & 75 \\
\hline New default model & -8.52 & -7.6 & -6.45 & -4.15 & -3 & -2.78 & -2.33 & -1.89 & -1 & \\
\hline New porosity model & -8.3 & -7.5 & -6.5 & -4.5 & -4.15 & -3.8 & -3.2 & -2.8 & -2 & -1.8 \\
\hline Old default model & -5.76 & -5.5 & -5.18 & -4.54 & -4.21 & -3.89 & -3.25 & -2.61 & -1.32 & -1 \\
\hline Broichhausen et al., Yang \& Aplin & -6.95 & -6.15 & -5.15 & -4.5 & -4.15 & -3.8 & -3.2 & -2.8 & -2 & -1.8 \\
\hline
\end{tabular}



Fig. 10. Porosity-permeability relationships of different models.

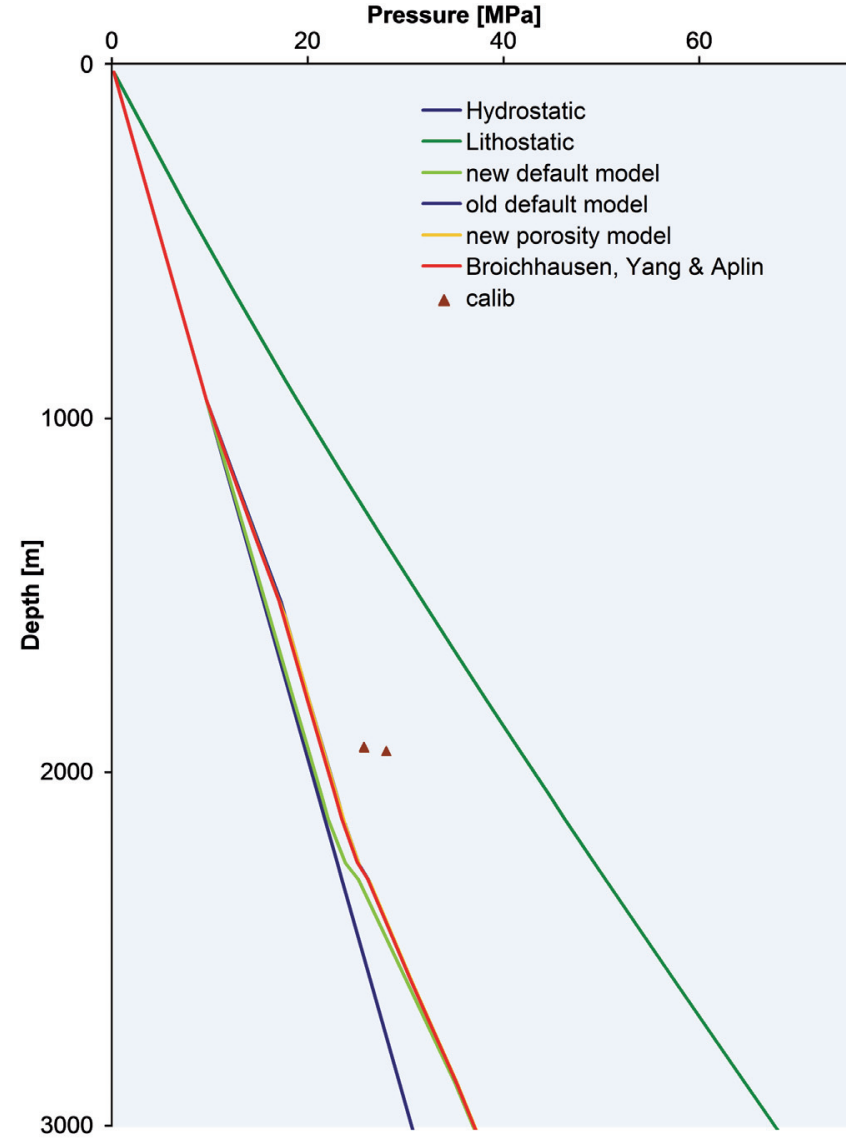

Fig. 11. Comparison of the effect of the different porosity-permeability relationship models. was modified based on published porosity and permeability measurements of the Chalk Group of Mallon \& Swarbrick (2002) to account for this effect (Table 5).

The mechanical compaction curve based on Athy's law fits the measured values in the upper, shallow part but it does not fit in the lower, deep part (Fig. 12). The modified curve based on the compressibility model fits the measured values in the uppermost, shallow part and in the deep part but does not fit in the middle. In addition to the mechanical compaction model, the porosity-permeability relationship was also changed based on measurements (Table 6, Fig. 13).

\section{Results and Discussion}

\section{Upper Mesozoic overpressures}

The overpressures measured in Cenozoic, Cretaceous and Jurassic rocks suggest the presence of a partially sealing top layer at least for water. Based on the measured overpressures it is difficult to determine which layer is responsible for the overpressures and when the sealing layer was sufficiently compacted to act as a seal. However, the widespread distribution of overpressures hints at a regional distribution of the top seal.

The Lower and Middle Cenozoic Lower North Sea Group is a thick Paleogene shale sequence of regional distribution and is the stratigraphically lowermost unit that could serve as top seal. Initial modelling using the new default lithologies (see 
Table 5. Porosity-depth relationship for the Chalk based on literature data from Mallon \& Swarbrick (2002) and the default and changed mechanical compaction models.

\begin{tabular}{|c|c|c|c|c|c|}
\hline \multicolumn{2}{|c|}{ Chalk (Mallon \& Swarbrick, 2002) } & \multicolumn{2}{|c|}{ Chalk new-Compressibility model } & \multicolumn{2}{|c|}{ Chalk default - Athy's law (depth) } \\
\hline Porosity (\%) & Depth (m) & Porosity (\%) & Depth (m) & Porosity (\%) & Depth (m) \\
\hline \multirow[t]{2}{*}{65} & 0 & 70 & 0 & 70 & 0 \\
\hline & & 55.7479 & 250 & 55.8961 & 250 \\
\hline \multirow[t]{2}{*}{50} & 500 & 45.801 & 500 & 44.634 & 500 \\
\hline & & 38.6878 & 750 & 35.6409 & 750 \\
\hline \multirow[t]{2}{*}{35} & 1000 & 33.2888 & 1000 & 28.4599 & 1000 \\
\hline & & 28.9886 & 1250 & 22.7257 & 1250 \\
\hline \multirow[t]{2}{*}{20} & 1500 & 25.4386 & 1500 & 18.1468 & 1500 \\
\hline & & 22.4279 & 1750 & 14.4905 & 1750 \\
\hline \multirow[t]{2}{*}{17.5} & 2000 & 19.8212 & 2000 & 11.5709 & 2000 \\
\hline & & 17.5273 & 2250 & 9.23957 & 2250 \\
\hline \multirow[t]{2}{*}{15} & 2500 & 15.482 & 2500 & 7.37795 & 2500 \\
\hline & & 13.6386 & 2750 & 5.89141 & 2750 \\
\hline \multirow[t]{2}{*}{12.5} & 3000 & 11.9622 & 3000 & 4.70439 & 3000 \\
\hline & & 10.4261 & 3250 & 3.75653 & 3250 \\
\hline \multirow[t]{2}{*}{10} & 3500 & 9.0094 & 3500 & 2.99965 & 3500 \\
\hline & & 7.69546 & 3750 & 2.39527 & 3750 \\
\hline \multirow[t]{2}{*}{7.5} & 4000 & 6.47083 & 4000 & 1.91266 & 4000 \\
\hline & & 5.32451 & 4250 & 1.52729 & 4250 \\
\hline 5 & 4500 & 5 & 4500 & 1.21957 & 4500 \\
\hline 5 & 7000 & 5 & 4750 & 1 & 4750 \\
\hline
\end{tabular}

methods), however, suggests that the compaction of the Lower Cenozoic shales was not sufficient to generate the overpressures (Fig. 14a). Better results were achieved by changing the lithology to the one with modified compaction and permeability (modified shale lithology, see methods). This affected the calibration of the model significantly and resulted in a different maturity and temperature evolution of the underlying units (Fig. 15). A calibration with changed lithology requires higher temperatures during the Cenozoic to fit the measured vitrinite reflectance, while the present-day temperature calibration stays approximately the same. Both scenarios are possible and cannot be verified or rejected without porosity and permeability measurements on rocks of Paleogene age.

Based on the lithological description of the wells that were drilled in the study area, a subdivision of the Pliocene to Quaternary Upper North Sea Group was introduced and the lithology of its lowermost part was changed to the modified shale lithology. In this scenario, overpressures in the Upper Mesozoic

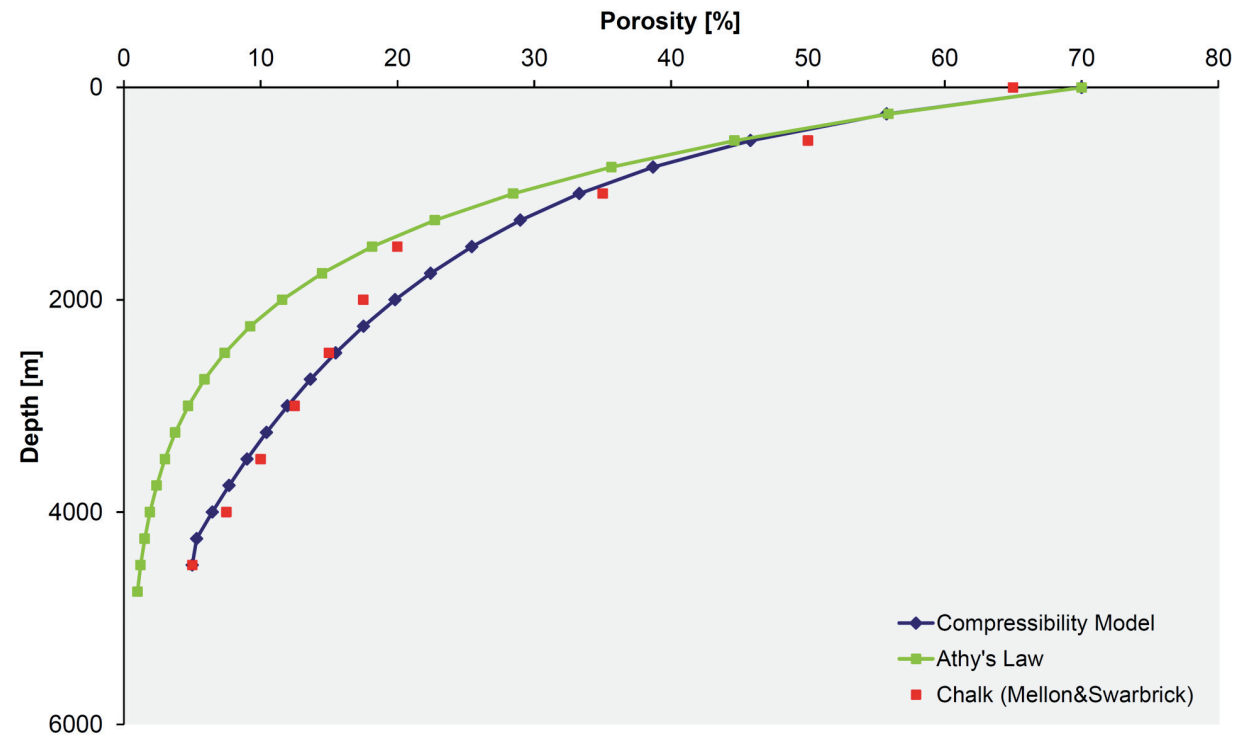

Fig. 12. Graphic illustration of the porosity-depth relationship of the literature data (red squares) and the default (yellow) and changed (blue) mechanical compaction models. 
Table 6. Porosity-permeability relationship of the Chalk of the default and of the changed model.

\begin{tabular}{|c|c|c|c|}
\hline \multicolumn{2}{|c|}{ Chalk new } & \multicolumn{2}{|c|}{ Chalk default } \\
\hline $\begin{array}{l}\text { Porosity } \\
(\%)\end{array}$ & $\begin{array}{l}\text { Permeability } \\
(\log \mathrm{mD})\end{array}$ & $\begin{array}{l}\text { Porosity } \\
(\%)\end{array}$ & $\begin{array}{l}\text { Permeability } \\
\text { (log } \mathrm{mD})\end{array}$ \\
\hline 5 & -6 & 1 & -6.75 \\
\hline 20 & -5 & 25 & -3.1 \\
\hline 75 & 3 & 70 & 1 \\
\hline
\end{tabular}

start to build as soon as the Pliocene sediments are deposited. By extending the current model by $5 \mathrm{Ma}$ into the future and assuming no further deposition, the rate of pressure dissipation was tested. The results show that pressure will dissipate with time ( 5.5 MPa less at $\sim 2000 \mathrm{~m}$ after $5 \mathrm{Ma}$ ), indicating a strong influence of the accumulation rate on the amount of overpressure. This was also confirmed by other modelling scenarios using faster burial rates and agrees with the observations of Verweij (2003). Modification of the mechanical compaction and porosity/permeability alone resulted in the modelling of higher overpressures, but the best results were achieved with a combination of fast sedimentation and modified lithologies.

The rapid accumulation is in agreement with previous studies from the northern part of the DCG, which identified sedimentation rates of up to $840 \mathrm{~m} / \mathrm{Ma}$, based on biostratigraphic age determinations (Kuhlmann et al., 2006).

In the Central Graben, overpressures measured in the Jurassic increase towards the south. This is in contradiction with the previous observation that links the amount of overpressure to the rate of sedimentation, as the sedimentary thickness of the Cenozoic sediments in the Central Graben increases towards the north. Verweij (2006) linked this amongst other things to the presence or absence or different hydraulic behaviour of the Chalk. The modified compaction and porosity/permeability model for the Chalk Group was not able to reproduce this effect (Fig. 14b), indicating that either the higher overpressures are

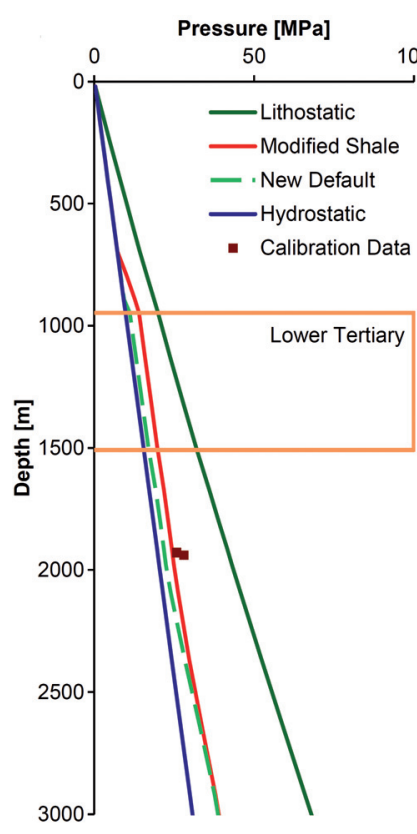

a.

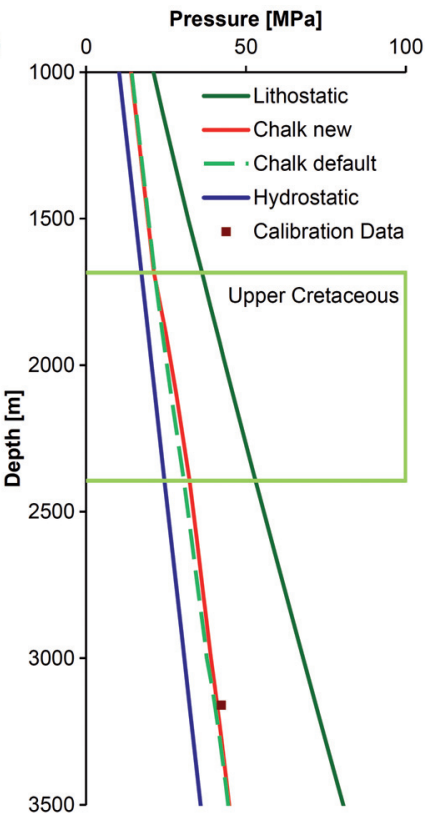

b.

Fig. 14. Calculated pressure difference between PetroMod default lithologies and modified lithologies for: a. the Paleogene shale in well L02-07; and b. the Upper Cretaceous Chalk in well L05-07.

not correlated with the presence of the Chalk Group or the hydraulic properties of the Chalk in the southern DCG are not related to mechanical compaction and cannot be described by the published relationships of Mallon \& Swarbrick (2002). Different mineral structure and composition as well as chemical compaction might have a bigger effect on the hydraulic properties of the Chalk and could explain the observed overpressures. A similar conclusion was published by Swarbrick et al. (2005) for the Central North Sea.

\section{Lower Triassic overpressures}

The main controlling process for the generation of overpressures in the Lower Triassic is the distribution of salt which
Fig. 13. Graphic illustration of the porositypermeability relationship of the Chalk.

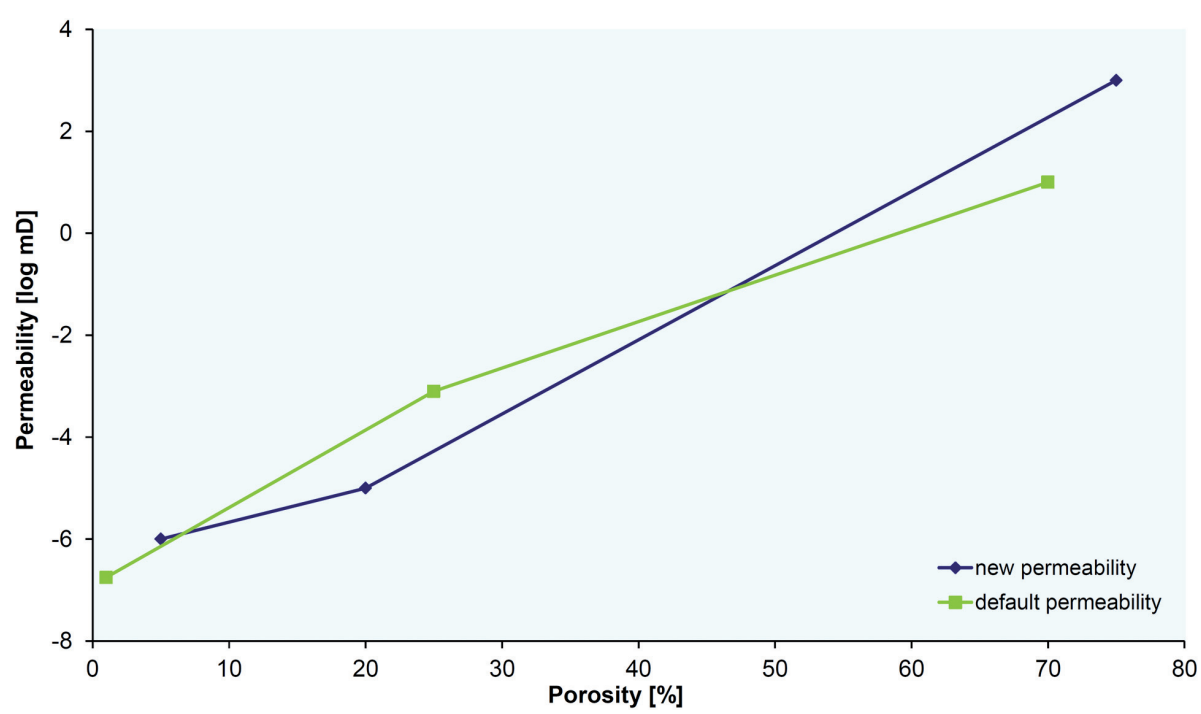






Fig. 15. Comparison of temperature history of the Early Triassic with standard (blue) and changed lithologies (orange). acts both as top and side seal. During the Late Permian, thick layers of salt were deposited in the study area. The original thickness of these salt deposits was estimated to be around $650 \mathrm{~m}$ (Verweij \& Witmans, 2009). At present the salt is concentrated in several large salt walls and diapirs that strongly influence the pressure distribution (Figs 5 and 6). During the Middle to Late Triassic several episodes of salt deposition were identified with a maximum present-day thickness of $300 \mathrm{~m}$ per layer in the DCG and not more than $150 \mathrm{~m}$ in the TB (Geluk, 2007). These layers show no significant contribution to the diapirism of the Zechstein salt but form a continuous top seal for the fluids in the Lower Triassic (Figs 5 and 6 ). Therefore, the most important parameter controlling the amount of overpressure in the Lower Triassic is the timing of salt movement and the lateral closure of the pressure compartments.

Salt moves as a result of differential loading, from areas of high load to areas of lower load. Load can be caused by overburden, tectonic processes such as extension or compression or temperature gradients in the salt (Hudec \& Jackson, 2007). Frictional forces between the salt layer and the over- and underlying sediments can inhibit flow. The magnitude of these forces is inversely related to the thickness of the salt layer, explaining the limited deformation of the Triassic salt layers.

The general timing of salt movement was linked to the major tectonic events that occurred in the study area. According to Remmelts (1996), the salt started to move in the Late Jurassic in the DCG and before the Middle Jurassic in the TB. The main phase of piercing occurred during the Late Jurassic to Early Cretaceous. Reactivation of salt movement occurred during Late Cretaceous-Paleogene phases of tectonic inversion (Table 7).

Based on this general description, three scenarios were selected to study the effect of the timing of the salt movement on the generation of overpressures. In the TB cross section (Figs 4 and 6; B-B'), a relatively small salt diapir forms the side seal of the middle part of the section towards the southern part with the transition to the Ameland Platform. Based on the timing of the closure of the pressure compartment, the pressure inside the compartment is either too high (very early closure) or too low (late closure, Fig. 16). The best calibration was reached with a start of the salt movement around $183 \mathrm{Ma}$ and a closure time of the pressure compartment at $140 \mathrm{Ma}$ (Fig. 16), which agrees very well with the description of Remmelts (1996).

In the DCG section the pressure calibration was not as sensitive to the timing of the salt movement as in the TB section. However, the best pressure calibration results were achieved with a start of piercing during the latest Triassic and a lateral closure of the pressure cells during the Early Jurassic (Fig. 17; Ten Veen et al., this issue). Piercing continued until the Late Jurassic but has no further effect on the overpressures in the Triassic. These results give an onset of salt movement that coincides with the Early Kimmerian tectonic phase, which is earlier than reported by previous studies (e.g. Remmelts,

Table 7. Comparison of ages used for the movement of the salt in the model with the geological description of the area

\begin{tabular}{|c|c|c|c|c|}
\hline & \multicolumn{2}{|l|}{ Southern Dutch Central Graben } & \multicolumn{2}{|l|}{ Terschelling Basin } \\
\hline & Geological description (Remmelts, 1996) & Model & Geological description (Remmelts, 1996) & Model \\
\hline $\begin{array}{l}\text { Depositional } \\
\text { thickness }\end{array}$ & $650 \mathrm{~m}$ & $\begin{array}{l}542 \text { m (based on } \\
\text { current thickness) }\end{array}$ & $650 \mathrm{~m}$ & $\begin{array}{l}260 \mathrm{~m} \text { (based on } \\
\text { current thickness) }\end{array}$ \\
\hline Start movement & Late Jurassic & 249-241 Ma & Before Middle Jurassic & $>183 \mathrm{Ma}$ \\
\hline Piercing age & Early Cretaceous & 203.6-145 Ma & Middle Jurassic to Early Cretaceous & $183-130 \mathrm{Ma}$ \\
\hline Reactivation & Late Cretaceous to Palaeogene & $<99 \mathrm{Ma}$ & Late Cretaceous to Palaeogene & $<105 \mathrm{Ma}$ \\
\hline
\end{tabular}




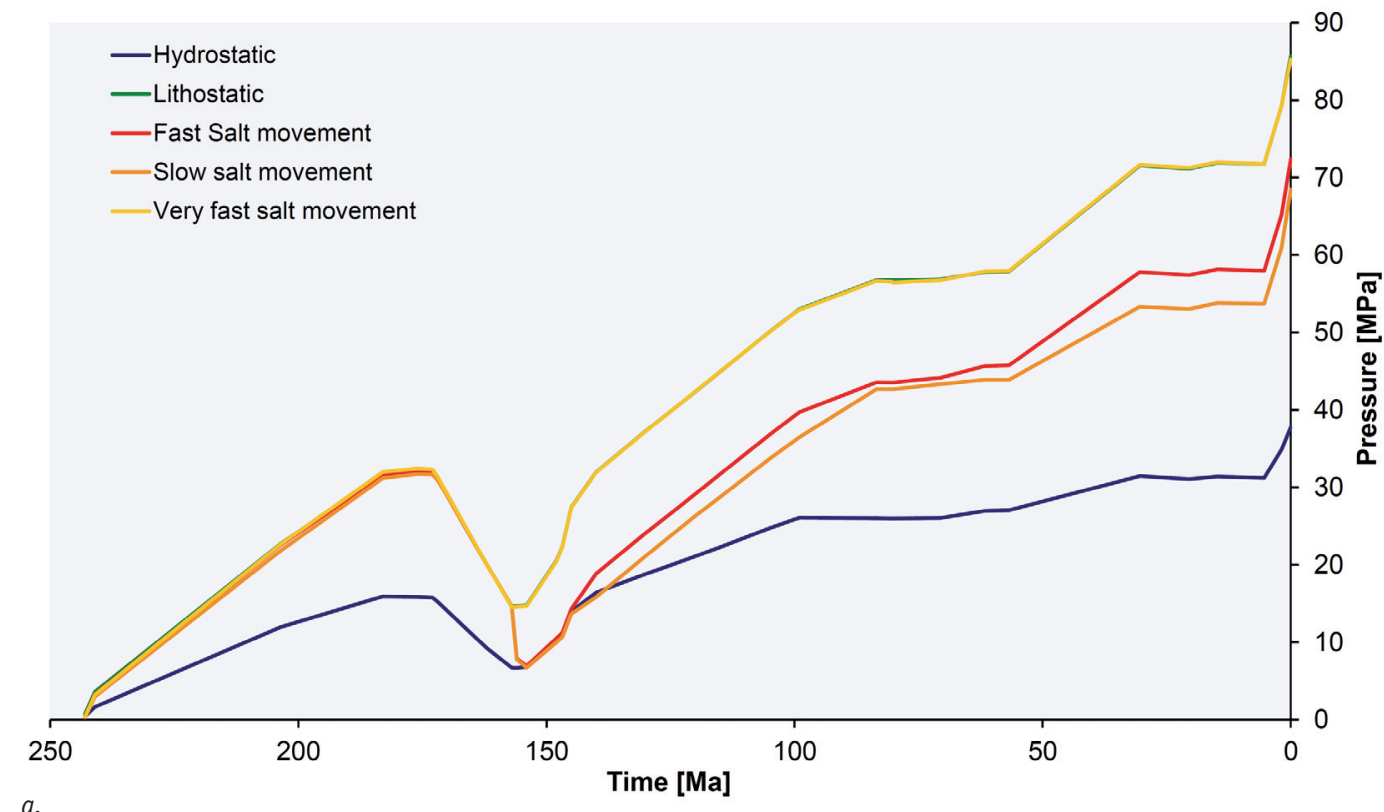

a.

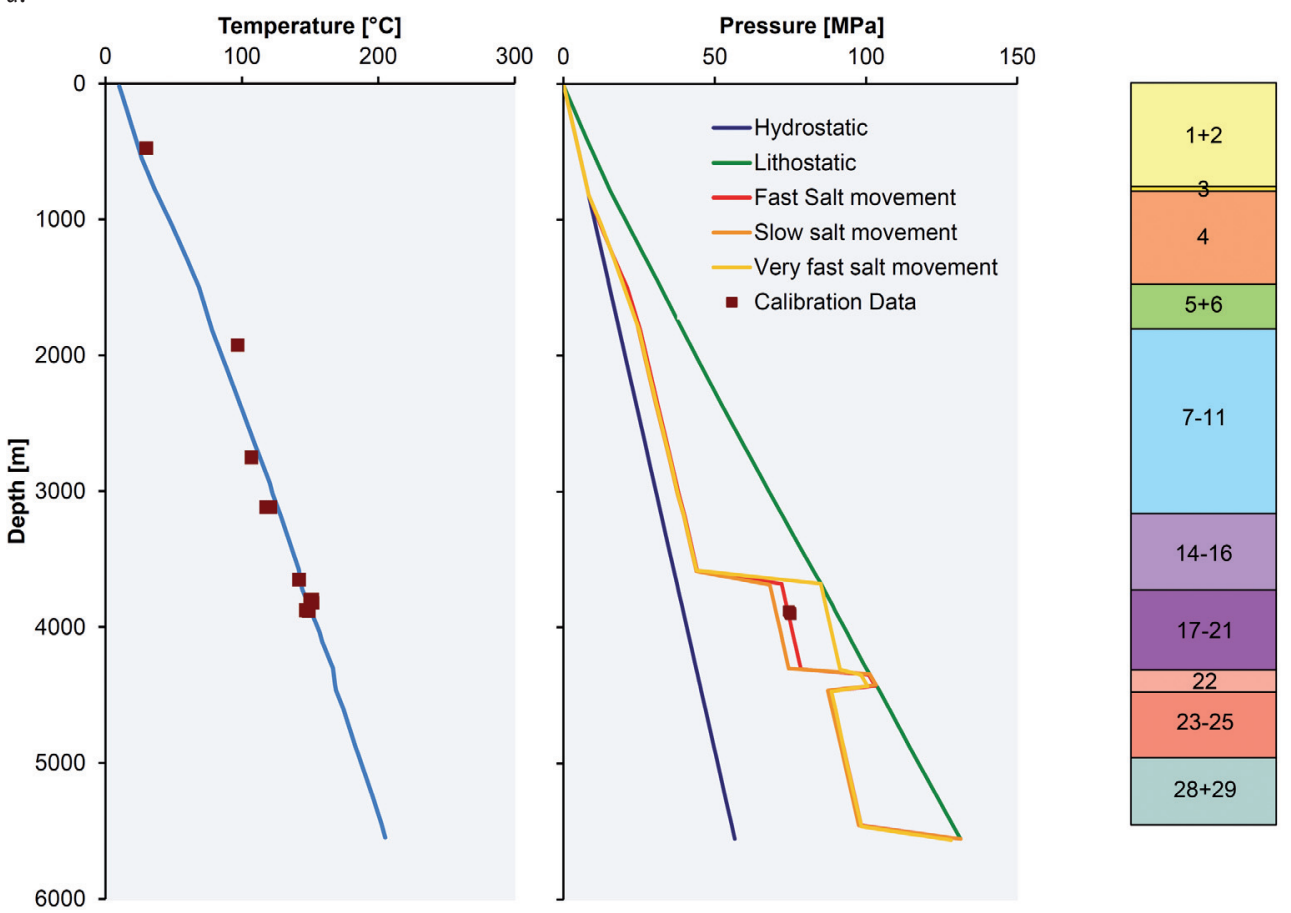

Fig. 16. Comparison of pressure calibration curves of different salt movement models at the position of well M01-02. a. Pressure evolution through time for the Lower Triassic reservoirs; $b$. pressure and temperature calibration at present day. For an explanation of the stratigraphy see Table 2.

1996). Looking at the porosity calibration data, the measured values are slightly lower than the calculated curve (Fig. 17). When the pressure compartment is closed, the porosity does not continue to decrease with increasing burial depth. The overestimation of the porosity could be an indication that the closure of the pressure compartment occurred later and that an additional process of overpressure generation, such as hydrocarbon generation and migration, plays a role. Another explanation could be chemical compaction influencing the measured porosity of the Lower Triassic rocks, which was not taken into account in this study. The results of the salt movement calibration based on pressures are summarised in Table 7.

\section{Initial salt thickness}

Ten Veen et al. (this issue) present a new method of calculating the initial salt thickness. They assume that salt movement is restricted laterally by major block-bounding faults and does not occur over large distances. Based on this assumption, they calculate the mean thickness for each structural element. The results of their method agree very well with the values for the initial salt thickness that were used for this study, which were based on the present-day thickness averaged for the whole 2D section without taking structural units into account (Table 7). On the other hand, $260 \mathrm{~m}$ of Zechstein salt is not a lot and based on the previously mentioned rule (frictional forces inhibiting 

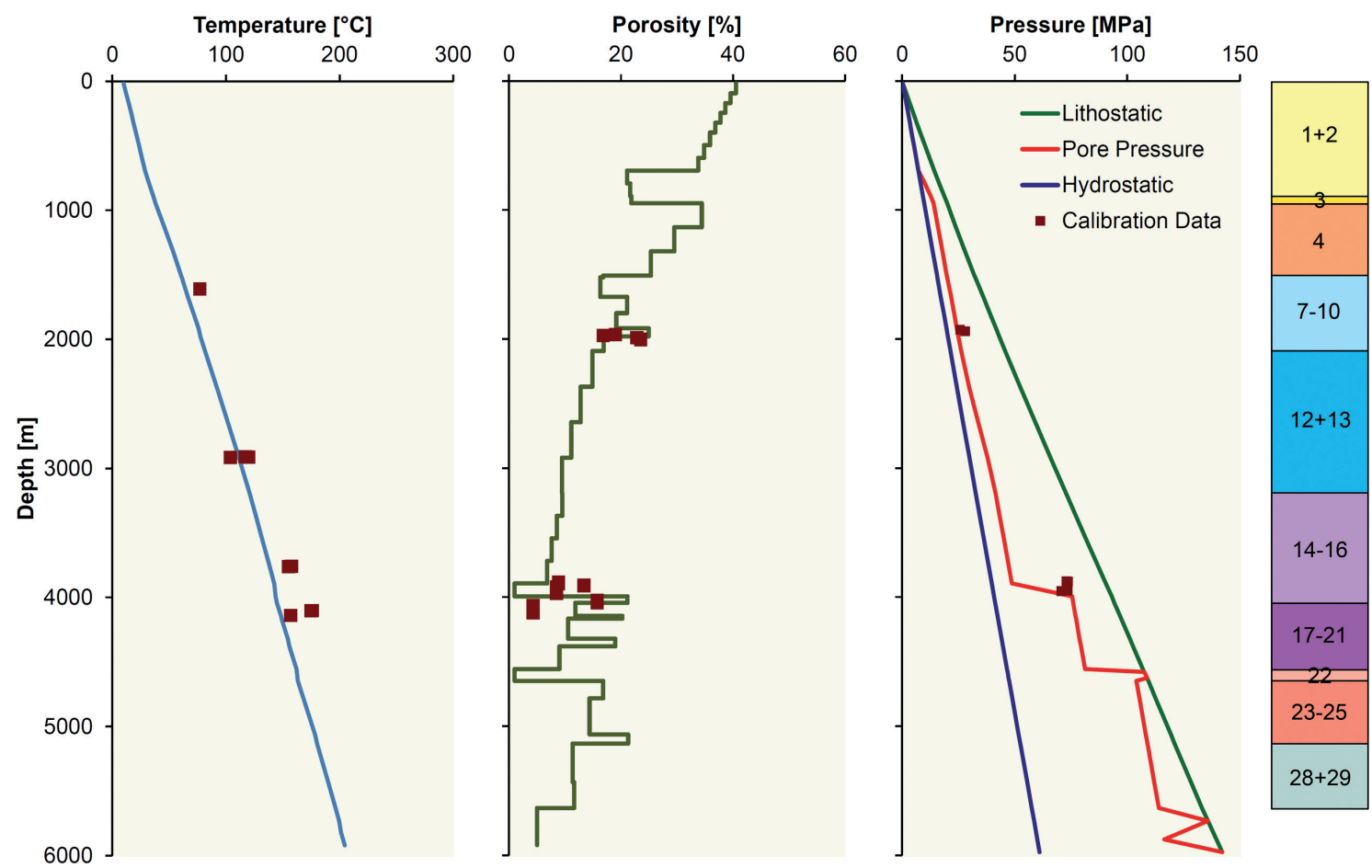

Fig. 17. Temperature, pressure and porosity calibration for well L02-07 in the DCG. For an explanation of the stratigraphy see Table 2.

salt flow are roughly inversely correlated to the thickness of the layer (Hudec \& Jackson, 2007), it is surprising that such a thin salt layer was intensely deformed by halokinesis. Remmelts (1996) mentions phases of truncation and dissolution of the salt structures in the TB during the Late Jurassic to Early Cretaceous. It is possible that the initial thickness of the salt in the TB was originally higher, but was significantly reduced during these phases. This, however, does not influence the results on the timing of the salt movement that are presented in this study.

\section{Implications for the petroleum system}

Overpressured sediments may pose drilling risks. On the other hand, such sediments may have retained better porosities and permeabilities compared to normally pressured sediments at the same burial depth. This can be favourable for production purposes in the case of a Chalk or sandstone reservoir. Differential overpressuring in reservoirs and mudstone seals influences the total seal capacity of the mudstone. If top seals are more overpressured than the underlying reservoirs, the downward directed overpressure gradients in the seal enhance the total seal capacity of the seal (Underschultz, 2007, 2009). The compaction of a mudstone and the related overpressures are therefore quite important to identify possible hydrocarbon accumulations.

This study shows that the Paleogene and or the lowermost Pliocene in the study area are possibly acting as vertical low permeability barriers delaying vertical flow of water. These low permeability mudstones may also act as permeability and capillary pressure seals for hydrocarbons. The so-called Hanze oil field in the northern offshore region of the Netherlands, situated north of the study area is an example for the sealing capacity of the Lower Cenozoic shales. The Hanze field is an overpressured commercial oil field situated in an uppermost Cretaceous fractured Chalk reservoir, sealed by Lower Cenozoic shales (Hofmann et al., 2002). Even though overpressure and hydrocarbon shows have been encountered in the permeable zones of the Lower Cenozoic, this is believed to be related to leakage along fractures and not to a weak seal.

Zechstein salt is known to form the top and side seals for many Rotliegend gas fields (De Jager \& Geluk, 2007). In this study the Zechstein salt acts as side seal and Triassic salt as top seal capable of holding large water overpressures in the Triassic reservoir horizons. It is therefore reasonable to assume that these seals are also capable of holding hydrocarbons.

Knowing the timing of side seal closure is very important in order to assess the possibility of hydrocarbon accumulation in Triassic reservoir layers. This study suggests that the top and lateral seals for the Triassic reservoir horizons were formed quite early ( 150 Ma; Fig. 16) and appear to be very stable until present.

\section{Conclusions}

Basin modelling is a useful tool to assess the spatial and temporal evolution of pressure in a sedimentary basin. It can aid in the identification of hydraulic seals, overpressured compartments and solve timing issues for hydrocarbon migration and accumulation. 
- Fast burial and fast mechanical compaction of the Lower Neogene mudstones can explain most of the overpressures measured in Jurassic and Cretaceous rocks.

- Distribution and hydraulic properties of the Chalk probably have an influence on the amount of overpressures in Jurassic rocks in the Dutch Central Graben. This, however, does not appear to be related to the mechanical compaction of the Chalk. Including other effects, e.g. mineral dissolution and precipitation, might give better results.

- The timing of salt movement and related closure of lateral seals is very important for the generation of overpressures in Triassic rocks. Pressure and porosity measurements can be used as calibration data for basin modelling in addition to structural studies to determine the timing of salt movement.

- The 2D basin models could not be perfectly calibrated to the pressure and porosity measurements. Either the modelled pressure was too low in the case of a later pressure seal closure, or porosity was too high in the case of an early closure. The reduction of porosity by chemical processes (mineral precipitation, etc.) is one possible explanation. Another option is the increase of pressure due to hydrocarbon migration into the pressure cell.

- Knowledge of the mechanical compaction and formation of top and lateral seals helps identifying drilling hazards, but also possible hydrocarbon traps.

\section{Acknowledgements}

We would like to thank Schlumberger for giving us the opportunity to use their software PetroMod during this study. We are also very thankful for the comments and improvements suggested by the two reviewers Peter Kukla and Johan ten Veen. We would like to thank TNO for giving us the opportunity to publish this work.

\section{References}

Athy, L.F., 1930. Density, porosity and compaction of sedimentary rocks. American Association of Petroleum Geophysicists Bulletin 14: 1-24.

Benedictus, T., 2007. Determination of petrophysical properties from well logs of the offshore Terschelling Basin and southern Central North Sea Graben region (NCP-2A) of the Netherlands. TN0 report no. 2007-U-R0169/A (Utrecht).

Broichhausen, H., Littke, R. \& Hantschel, T., 2005. Mudstone compaction and its influence on overpressure generation, elucidated by a 3D case study in the North Sea. International Journal of Earth Sciences 94: 956-978.

De Jager, J., 2003. Inverted basins in the Netherlands, similarities and differences. Netherlands Journal of Geosciences 82: 355-366.

De Jager, J., 2007. Structural setting. In: Wong, T.E., Batjes, D.A.J. \& De Jager, J. (eds): Geology of the Netherlands. Royal Netherlands Academy of Arts and Sciences (KNAW) (Amsterdam): 1-23.
De Jager, J., Doyle, M.A., Grantham, P.J. \& Mabillard, J.E., 1996. Hydrocarbon habitat of the West Netherlands Basin. In: Rondeel, H.E., Batjes, D.A.J. \& Nieuwenhuijs, W.H. (eds): Geology of gas and oil under the Netherlands. Kluwer Academic Publishers (Dordrecht): 191-210.

De Jager, J. \& Geluk, M.C., 2007. Petroleum geology. In: Wong, T.E., Batjes, D.A.J. \& De Jager, J. (eds): Geology of the Netherlands. Royal Netherlands Academy of Arts and Sciences (KNAW) (Amsterdam): 241-264.

DiPrimio, R. \& Neumann, V., 2008. HPHT reservoir evolution: a case study from Jade and Judy fields, Central Graben, UK North Sea. International Journal of Earth Sciences 97: 1101-1114.

Donders, T.H., Weijers, J.W.H., Munsterman, D.K., Kloosterboer-van Hoeve, M.L., Buckles, L.K., Pancost, R.D., Schouten, S., Sinninghe Damste, J.S. \& Brinkhuis, H., 2009. Strong climate coupling of terrestrial and marine environments in the Miocene of northwest Europe. Earth and Planetary Science Letters 281: 215-225.

Geluk, M.C., 2007. Triassic. In: Wong, T.E., Batjes, D.A.J. \& De Jager, J. (eds): Geology of the Netherlands. Royal Netherlands Academy of Arts and Sciences (KNAW) (Amsterdam): 85-106.

Glennie, K.W., 1986. Development of N.W. Europe's southern Permian gas basin. In: Brooks, J., Goff, J.C. \& Van Hoorn, B. (eds): Habitat of Palaeozoic Gas in N.W. Europe. Geological Society Special Publication (London): 3-22.

Hedberg, H.D., 1974. Relation of methane generation to undercompacted shales, shale diapirs and mud volcanoes. American Association of Petroleum Geologists Bulletin 58: 661-673.

Hofmann, A.P., Price, A., Kaffenberger, G., Godderij, R. \& Simpson, M., 2002. Hanze Chalk Oil Field - the Chalk Pearl in the Dutch North Sea. Abstract of the EAGE 64th Conference \& Exhibition, Florence, Italy.

Holm, G.M., 1998. Distribution and origin of overpressure in the Central Graben of the North Sea. In: Law, B.E., Ulmishek, G.F. \& Slavin, V.I. (eds): Abnormal pressure in hydrocarbon environments. AAPG Memoir v. 70: 123-144.

Hudec, M.R. \& Jackson, M.P.A., 2007. Terra infirma: understanding salt tectonics. Earth Science Reviews 82: 1-28.

Kombrink, H., Doornenbal, J.C., Duin, E.J.T., Den Dulk, M., Van Gessel, S.F., Ten Veen, J.H. \& Witmans, N., 2012. New insights into the geological structure of the Netherlands; results of a detailed mapping project. Netherlands Journal of Geosciences 91-4: 419-446, this issue.

Kuhlmann, G., Langereis, C.G., Munsterman, D., Van Leeuwen, R.J., Verreussel, R., Meulenkamp, J.E. \& Wong, T.E., 2006. Chronostratigraphy of Late Neogene sediments in the southern North Sea Basin and paleoenvironmental interpretations. Palaeogeography, Palaeoclimatology, Palaeoecology 239: 426-455.

Luo, X.R. \& Vasseur, G., 1996. Geopressuring mechanism of organic matter cracking: Numerical modelling. American Association of Petroleum Geologists Bulletin 80: 856-874.

Mallon, A.J. \& Swarbrick, R.E., 2002. A compaction trend for non-reservoir North Sea Chalk. Marine and Petroleum Geology 19: 527-539.

Mann, D.M. \& Mackenzie, A.S., 1990. Prediction of pore fluid pressures in sedimentary basins. Marine and Petroleum Geology 7: 55-65.

Mosbrugger, V., Utescher, T. \& Dilcher, D.L., 2005. Cenozoic continental climatic evolution of Central Europe. PNAS 102: 14964-14969.

Moss, B., Barson, D., Rakhit, K., Dennis, H. \& Swarbrick, R., 2003. Formation pore pressures and formation waters. In: Evans, D., Graham, C., Armour, A. \& Bathurst, P. (eds): The Millennium Atlas: Petroleum Geology of the Central and Northern North Sea. Geological Society (London): 317-329. 
Osborne, M.L. \& Swarbrick, R.E., 1997. Mechanisms for generating overpressure in sedimentary basins: a reevaluation. American Association of Petroleum Geologists Bulletin 81: 1023-1041.

Rattey, P.R. \& Hayward, A.B., 1993. Sequence stratigraphy of a failed rift system: the Middle Jurassic to Early Cretaceous basin evolution of the Central and Northern North Sea In: Parker, J.R. (ed.): Petroleum Geology of North-West Europe: Proceedings of the 4th Conference. The Geological Society (London): 213-249.

Remmelts, G., 1996. Salt tectonics in the southern North Sea, the Netherlands. In: Rondeel, H.E., Batjes, D.A.J. \& Nieuwenhuijs, W.H. (eds): Geology of gas and oil under the Netherlands. Kluwer Academic Publishers (Dordrecht): 143-158.

Sluijs, A., Schouten, S., Pagani, M., Woltering, M., Brinkhuis, H., Sinninghe Damsté, J.S., Dickens, G.R., Huber, M., Reichart, G.-J., Stein, R., Matthiessen, J., Lourens, L.J., Pedentchouk, N., Backman, J., Moran, K. \& the Expedition Scientists, 2006. Subtropical Arctic 0cean temperatures during the Palaeocene/ Eocene thermal maximum. Nature 441: 610-613.

Swarbrick, R.E., Seldon, B. \& Mallon, A.J., 2005. Modelling the Central North Sea pressure history. Geological Society (London), Petroleum Geology Conference series, v. 6: 1237-1245.

Ten Veen, J.H., Van Gessel, S.F. \& Den Dulk, M., 2012. Thin- and thick-skinned salt tectonics in the Netherlands; a quantitative approach. Netherlands Journal of Geosciences 91-4: 447-464, this issue.

Underschultz, J.R., 2007. Hydrodynamics and membrane seal capacity. Geofluids 7: 148-158.

Underschultz, J.R., 2009. Identification of fault and top seal effectiveness through an integration of hydrodynamic and capillary analysis techniques. PhD thesis, Curtin University of Technology (Perth, Australia).

Van Adrichem Boogaert, H.A. \& Kouwe, W.F.P., 1993. Stratigraphic nomenclature of the Netherlands, revision and update by RGD and NOGEPA, Section A, General. Mededelingen Rijks Geologische Dienst 50: 1-40.

Vejbæk, O.V., 2008. On dis-equilibrium compaction as the cause for CretaceousPaleogene over-pressures in the Danish North Sea. American Association of Petroleum Geologists Bulletin 92: 165-180.

Verweij, J.M., 2003. Fluid flow systems analysis on geological timescales in onshore and offshore Netherlands, with special reference to the Broad Fourteens Basin. $\mathrm{PhD}$ thesis, Vrije Universiteit Amsterdam (Amsterdam), $278 \mathrm{pp}$.

Verweij, J.M., 2006. Dual hydraulic behaviour of the Chalk in the Netherlands North Sea. Journal of Geochemical Exploration 89: 405-408.

Verweij, J.M., Souto Carneiro Echternach, M. \& Witmans, N., 2009. Terschelling Basin and southern Dutch Central Graben. Burial history, temperature, source rock maturity and hydrocarbon generation - Area 2A. TNO (Utrecht). Report number 034-UT-2009-02065.

Verweij, J.M., Souto Carneiro Echternach, M., Witmans, N. \& Abdul Fattah, R., 2012. Reconstruction of basal heat flow, surface temperature, source rock maturity and hydrocarbon generation in salt-dominated Dutch Basins. In: Peters, K., Curry, D. \& Kacewicz, M. (eds): Basin Modeling: New horizons in research and applications. AAPG Hedberg Series: 1-22.

Verweij, J.M. \& Witmans, N., 2009. Terschelling Basin and southern Dutch Central Graben Mapping and modeling - Area 2A. TN0 Built Environment and Geosciences (Utrecht). Report number TN0-034-UT-2009-01569, 65 pp.

Yang, Y. \& Aplin, A.C., 2007. Permeability and petrophysical properties of 30 natural mudstones. Journal of Geophysical Research 112: 1911-1918.
Ziegler, P.A., 1990. Geological Atlas of Western and Central Europe ( $2^{\text {nd }}$ edition). Shell Internationale Petroleum Maatschappij B.V.; Geological Society Publishing House (Bath), $239 \mathrm{pp}$.

Ziegler, P.A., 2005. Europe: Permian to Recent Evolution. In: Selley, R.C., Cocks, L.R.M. \& Plimer, I.R. (eds): Encyclopedia of Geology. Elsevier: 102-125. 